CAMILA ERCOLINI BARROSO

\title{
Estudo quantitativo da vascularização do timo em gatos
}

SÃO PAULO 


\section{Estudo quantitativo da vascularização do timo em gatos}

Dissertação apresentada ao Programa de PósGraduação em Anatomia dos Animas Domésticos e Silvestres da Faculdade de Medicina Veterinária e Zootecnia da Universidade de São Paulo para obtenção do título de Mestre em Ciências.

\section{Departamento:}

Cirurgia

Área de concentração:

Anatomia dos Animais Domésticos e Silvestres

Orientador:

Prof. Dr. Pedro Primo Bombonato

SÃO PAULO 
Autorizo a reprodução parcial ou total desta obra, para fins acadêmicos, desde que citada a fonte.

DADOS INTERNACIONAIS DE CATALOGAÇÃO-NA-PUBLICAÇÃO

(Biblioteca Virginie Buff D’Ápice da Faculdade de Medicina Veterinária e Zootecnia da Universidade de São Paulo)

Barroso, Camila Ercolini

Estudo quantitativo da vascularização do timo em gatos / Camila Ercolini Barroso. - São Paulo: C. E. Barroso, 2007.

$81 \mathrm{f}$. : il.

Dissertação (mestrado) - Universidade de São Paulo. Faculdade de Medicina Veterinária e Zootecnia. Departamento de Cirurgia, 2007.

Programa de Pós-Graduação: Anatomia dos Animais Domésticos e Silvestres.

Área de concentração: Anatomia dos Animais Domésticos e Silvestres.

Orientador: Prof. Dr. Pedro Primo Bombonato.

1. Timo (glândula endócrina). 2. Linfócitos T. 3. Sistema linfático. 4. Morfometria. 5. Gatos. I. Título. 


\section{UNIVERSIDADE DE SÃO PAULO \\ Faculdade de Medicina Veterinária e Zootecnia \\ Comissão Bioética}

\section{CERTIFICADO}

Certificamos que o Projeto intitulado "Estudo quantitativo da vascularização do timo em gatos", protocolado sob o n⿳922/2006, utilizando 10 (dez) gatos domésticos, sob a responsabilidade do Prof. Dr. Pedro Primo Bombonato, está de acordo com os princípios éticos de experimentação animal da Comissão de Bioética da Faculdade de Medicina Veterinária e Zootecnia da Universidade de São Paulo e foi aprovado em reunião de 16/08/06".

(We certify that the Research "Quantitative study of the thymus vascularization in cats", protocol number 922/2006, utilizing 10 (ten) cats, under the responsibility of Prof. Dr. Pedro Primo Bombonato, agree with Ethical Principles in Animal Research adopted by Bioethic Commission of the Faculty of Veterinary Medicine and Zootechny of University of São Paulo and was approved in the meeting of the day $08 / 16 / 2006)$.

São Paulo, 17 de agosto de 2006

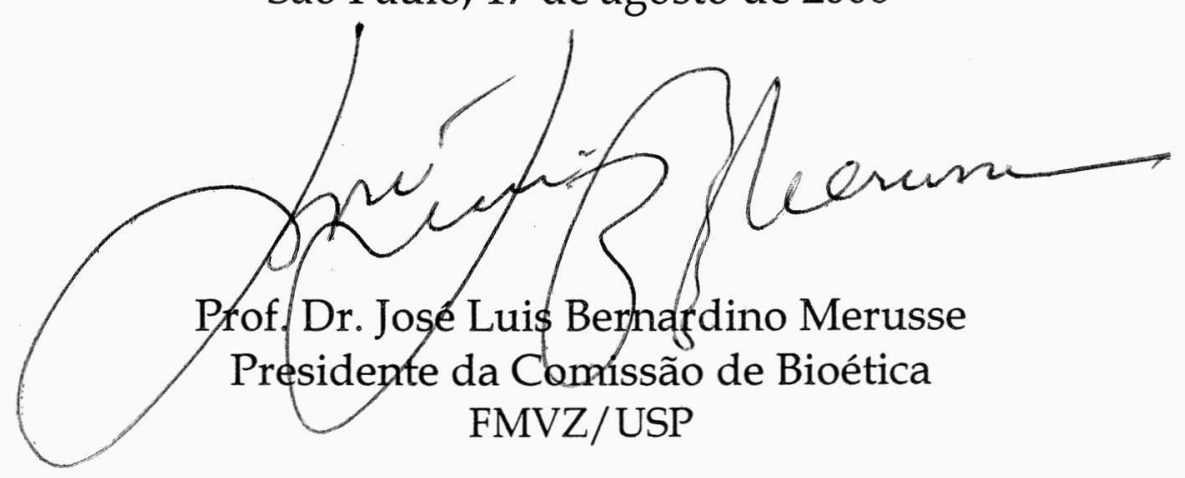




\section{FOLHA DE AVALIAÇÃO}

Nome: BARROSO,Camila Ercolini

Título: Estudo quantitativo da vascularização do timo em gatos

Dissertação apresentada ao Programa de PósGraduação em Anatomia dos Animais Domésticos e Silvestres da Faculdade de Medicina Veterinária e Zootecnia da Universidade de São Paulo para obtenção do título de Mestre em Ciências

Data:

1

Banca examinadora

Prof. Dr.: Instituição:

Assinatura: Julgamento:

Prof. Dr.: Instituição:

Assinatura: Julgamento:

Prof. Dr.: Instituição:

Assinatura: Julgamento: 
Dedico esse trabalho com amor e carinho

Aos meus honráveis pais, Márcio e Isabel, que sempre lutaram por mim e estiveram ao meu lado em todos os momentos.

À minha grande irmã Caroline

Ao meu querido orientador Prof. Pedro Primo Bombonato, agradeço imensamente a oportunidade, a paciência, a amizade, confiança e o mestre que foi além de amigo. 


\section{AGRADECIMENTOS}

A Deus pela oportunidade de viver, crescer e aprender sempre....

“Eu sou o pão da vida. Quem vêm a mim, nunca mais terá fome, e o que crê em mim nunca mais terá sede".

(João 6, 35) 
Ao André por todos os momentos que vivenciamos juntos. 
À Faculdade de Medicina Veterinária e Zootecnia da Universidade de São Paulo (FMVZ-USP) que me acolheu e proporcionou a subida de mais um degrau em minha formação.

Aos meus avós, Aníbal (in memoriam) e Margarida, que sempre me ofertaram carinho e amor em todos os momentos.

Aos meus tios, Regina e Edmar, Marcos e Salete, e meus primos Francisco e Bruno, Sofia e Sara, que sempre me ofertaram carinho e atenção em todos os momentos.

Ao Prof. Dr. Carlos Mandarim-de-Lacerda por nos receber em seu laboratório, pelos ensinamentos e explicações sobre a metodologia e pela atenção que nos foi ofertada neste período.

Aos professores e funcionários do setor de Anatomia dos Animais Domésticos e Silvestres do Departamento de Cirurgia da Faculdade de Medicina Veterinária e Zootecnia da Universidade de São Paulo (FMVZ-USP). Agradeço a atenção, oportunidade e ensinamentos.

Ao Prof. Dr. Francisco Javier Hernandez Blazquez por ceder seu laboratório para o desenvolvimento de pesquisa e pelos ensinamentos em disciplinas.

À Prof. Dra. Maria Angélica Miglino por me acolher e permitir o desenvolvimento deste trabalho no departamento.

À Shirley, técnica do laboratório de microscopia eletrônica do Departamento de Patologia, pela ajuda no processamento do material.

Ao meu amigo técnico Edinaldo Ribas Farias ("Índio") pela amizade e companheirismo e aos técnicos Ronaldo Agostinho da Silva e Diogo Palermo.

Aos secretários Maicon e Jaqueline pela atenção e carinho.

Aos funcionários da pós graduação e da biblioteca da FMVZ-USP pelo carinho, paciência e atenção. 
À Fernanda Agreste ("Fer") por todo os ensinamentos, risadas, companhia, atenção, paciência e amizade.

Ao Fábio Hosoi Rezende ("Peixe”) pela ajuda nas fotos e pela grande amizade.

Ao Caio por todo tempo compartilhado, atenção, amizade e o grande carinho.

Aos amigos do museu Fátima de Lourdes Minari, Tatiana Curti, Natália Garcia de Andrade ("Branca"), João do Carmo Freitas ("Pele"), Raimundo Leal de Sousa ("Ray") pelas risadas, companhia e amizade.

Ao Hildebrando Gomes Benedicto pela ajuda e atenção.

Às minhas colegas de república Juliana Guimarães e Renata Mari pelo apoio e amizade.

Aos meus amigos de pós-graduação - Gerlane de Medeiros, Marcos Ivo (Marcão), Alexandre, Felipe (Felipinho), André, João, Cristiane Wenceslau, Rosemary Viola Bosh, Janaína Munueira Monteiro, Ana Rita, Renata, Ana Paula (Paulinha), Cinthia, Thiago Aloia, Walquíria (Val),.....

Aos meus cães Pandora, Hanna e o meu gato Binks pelo exemplo de fidelidade e amor incondicional ofertado.

E por todos os animais que cederam sua vida para a realização deste trabalho, os meus mais sinceros votos de agradecimento e ternura.

\section{À todos que participaram direta ou indiretamente para a realização deste} trabalho, os meus sinceros agradecimentos! 


\section{RESUMO}

BARROSO, C. E. Estudo quantitativo da vascularização do timo em gatos. [Quantitative study of the thymus vascularization in cats]. 2007. $81 \mathrm{f}$. Dissertação (Mestrado em Ciências) - Faculdade de Medicina Veterinária e Zootecnia, Universidade de São Paulo, São Paulo, 2007.

O timo é um órgão de grande importância imunológica durante a vida fetal e no período neonatal, para que o indivíduo se torne imunocompetente. É considerado, anatomicamente, o maior órgão com alta atividade linfopoiética no indivíduo jovem. $\mathrm{O}$ timo dos gatos apresenta duas porções, torácica e cervical, onde cada uma delas apresenta um lobo direito e esquerdo em sua maioria. A maior contribuição vascular origina-se da artéria torácica interna esquerda e do tronco braquiocefálico. Possui coloração rósea-pálido, localizado em região de mediastino cranial, entre os pulmões e na base do coração a porção torácica, e a porção cervical estende-se além das costelas em sentido cranial localizada ventralmente a traquéia. Foram utilizados 12 fetos de gatos domésticos, sem raça definida, machos e fêmeas, divididos em três grupos. Os timos foram processados para o estudo da microscopia de luz, e as análises estereológicas foram realizadas utilizando o método disector físico associado com o princípio de ConnEuler. As variações de volume, comprimento, espessura e largura de maneira geral apresentaram aumento conforme o desenvolvimento dos animais, com diferenças entre os sexos. As medidas estereológicas relativas a densidade numérica vascular $\left(\mathrm{Nv}_{\text {(vasc) }}\right)$ apresentam-se maiores nas fêmea, ocorrendo uma diminuição gradativa e o número total de vasos no órgão $\left(\mathrm{N}_{(\mathrm{vasc})}\right)$ apresentou valores maiores nos machos com uma diminuição gradual. A estimação da densidade do comprimento do vaso (Lv) e da densidade de superfície de área (Sv) apresentaram diminuição aos 45 dias de idade, e a densidade do comprimento do vaso (Lv) apresentou valor maior nos machos de 35 e 55 dias, enquanto que na densidade de superfície de área (Sv) os valores variaram entre os sexos.

Palavras-chave: Timo (glândula endócrina). Linfócitos T. Sistema Linfático. Morfometria. Gatos. 


\begin{abstract}
BARROSO, C. E. Quantitative study of the thymus vascularization in cats. [Estudo quantitativo da vascularização do timo em gatos]. 2007. $81 \mathrm{f}$. Dissertação (Mestrado em Ciências) - Faculdade de Medicina Veterinária e Zootecnia, Universidade de São Paulo, São Paulo, 2007.
\end{abstract}

During the phoetal life and neonatal period, the thymus has a great importance to became an individual healthy. Anatomically is the largest organ with high limphopoietic activity in young individual. The cat thymus presents two portions, thoracic and cervical, where each one of them presents a right and left lobe at the most. The major contribution initiates from the inner thoracic artery and from braquicephalicus trunk. The organ presents pink-pale color, located in region of cranial mediastine, between lungs and at the base of the heart; the thoracic portion and the cervical extend beyond the ribs located ventrally to the trachea. For this study were used twelve fetus of the mongrel domestic cats, males and females, divided into three groups. The thymus were processed for the light-microscopy, and the stereological analyses were done using the physical disector method associated with the ConnEuler principle. The volume of the organ, lenght, thickness and wide increased gradually with the development, with diferences between sex. The stereological variables related to vascular number density $\left(\mathrm{Nv}_{\text {(vasc })}\right)$ were greater in females, decreasing gradually and the vascullar total number $\left(\mathrm{N}_{\text {(vasc) }}\right)$ were greater in males decreasing gradually. The lenght density (Lv) and the surface area density showed decreasing at forty-five days old, and the lenght density were greater in males ate thirty-five and fifty-five days old, while the surface area density the values were varied between sex.

Key-words: Thymus (endocriny gland). T lymphocyte. Lymphatic system. Morfometry. Cats 


\section{LISTA DE ABREVIATURAS E SÍMBOLOS}

\begin{tabular}{|c|c|}
\hline $\mathrm{mm}$ & milímetro \\
\hline $\mathrm{cm}$ & centímetro \\
\hline SNA & sistema nervoso autônomo \\
\hline B & beta \\
\hline SRD & sem raça definida \\
\hline PBS & solução salina tamponada fosfatada \\
\hline M & molar \\
\hline${ }^{\circ} \mathrm{C}$ & Graus Celsius \\
\hline$\mu \mathrm{m}$ & micrômetro \\
\hline$V_{\text {(ref) }}$ & Volume Referência \\
\hline$d$ & distância para cortes macroscópicos \\
\hline$k$ & distância para cortes microscópicos \\
\hline$\Sigma a$ & somatória das áreas \\
\hline CE & coeficiente de erro \\
\hline AUI & Aleatórios e Uniformemente Isotrópicos \\
\hline IUR & Isotropic Uniform Random \\
\hline$\Phi$ & seno \\
\hline$\Theta$ & co-seno \\
\hline $\mathrm{mm}^{2}$ & milímetro quadrado \\
\hline a & área \\
\hline $\mathrm{p}$ & número de pontos \\
\hline
\end{tabular}




$\begin{array}{ll}\text { ht } & \text { altura } \\ \mathrm{V}_{(\text {dis })} & \text { área teste } \\ \mathrm{H} & \text { nolume do disector } \\ \mathrm{I} & \text { island } \\ \mathrm{B} & \text { bridge } \\ \mathrm{X}_{\mathrm{v}} & \text { número de Euler } \\ \mathrm{N}_{\mathrm{v}(\mathrm{vasc})} & \text { densidade numérica vascular } \\ \mathrm{N}_{(\mathrm{vasc})} & \text { número de vasos } \\ \mathrm{L} & \text { comprimento do vaso } \\ \mathrm{Lv} & \text { densidade de comprimento do vaso } \\ \mathrm{S} & \text { superfície de área } \\ \mathrm{Sv} & \text { densidade de superfície de área } \\ \mathrm{Qa} & \text { número de perfis por área } \\ \mathrm{I} & \text { número de intersecções } \\ \mathrm{Cm} & \text { centímetro cúbico } \\ & \text { desvio padrão } \\ & \end{array}$




\section{LISTA DE FIGURAS}

Figura 1 - Ilustração demonstra a cavidade torácica de gato com os pulmões seccionados. Timo (seta preta); A: brônquios seccionados e vasos pulmonares; B: coração com pericárdio; C: nervo frênico; $\mathrm{D}$ : veia cava caudal; $\mathrm{E}$ : esôfago; F: aorta. (Fonte: Hudson; Hamilton, 1993)

Figura 2 - Sistemas testes com diferentes ângulos utilizados no método orientator. $A$ - relógio $\theta$ (co-seno) ou $\theta$ - clock. B - relógio $\phi$ (seno) ou $\phi$-clock

Figura 3 - Em A, a "reference section" é delimitada por uma área teste com linhas de inclusão (linhas pontilhadas) e de exclusão (linhas cheias). Em B, a "look-up section" é delimitada por uma área teste rígida.

Figura 4 - Amostragem do disector e estimação dos planos tangenciais. Em A, a superfície convexa do capilar é mostrado na "reference setion" e não na "Look-up section", estruturas chamadas de "Hole". Em B, uma irregularidade da parede do capilar é observada conferindo uma nova parte isolada chamada de "Island". Em C, na "reference section" a curvatura é côncava, e na "look-up section" a curvatura é do tipo convexa formando uma divisão do lúmen capilar em dois ou mais lumens, chamados também de "Bridge".

Figura 5 - Fotografia de região torácica de feto de gato com remoção da $2^{\mathrm{a}}$ até $4^{\mathrm{a}}$ costela torácica, evidenciando lobo tímico esquerdo (A) e lobo cranial pulmonar esquerdo (B)

Figura 6 - Fotografia de região torácica de feto de gato com remoção das costelas e deslocamento do pulmão direito (A) para evidenciar o timo direito (B)

Figura 7 - Fotografia de timo de feto de gato de 55 dias A: lobo tímico cervical esquerdo. B: lobo tímico torácico esquerdo. C: lobo pulmonar cranial esquerdo. D: 
coração. Seta preta: nervo vago. E: traquéia

55

Figura 8 - Histograma comparando as variáveis, volume referência, comprimento espessura e largura do timo entre as faixas etárias e o sexo. A: Volume referência $\left(V_{(\text {ref })}\right)$. B: comprimento do timo. C: espessura do timo. D: largura do timo - São Paulo -2007

Figura 9 - Fotomicrografias dos timos. A e B: feto com 55 dias, fêmea (Barra $40 \mu \mathrm{m})$. C e D: feto com 45 dias, fêmea

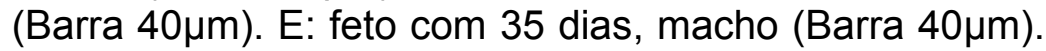

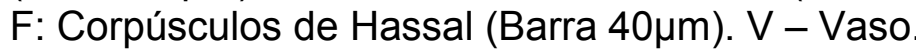
61 


\section{LISTA DE TABELAS}

Tabela 1 Valores das variáveis, volume referência $\left(\mathrm{V}_{(\mathrm{ref})}\right)$, comprimento, espessura largura do timo em fetos machos nos diferentes grupos etários. São Paulo - 2007 .

Tabela 2 Valores das variáveis, volume referência $\left(\mathrm{V}_{(\mathrm{ref})}\right)$, comprimento, espessura largura do timo em fetos fêmeas nos diferentes grupos etários. São Paulo - 2007

Tabela 3 Valores das variáveis densidade de comprimento do vaso (Lv), comprimento do vaso (L), densidade de superfície de área (Sv), superfície de área (S), estimação da densidade numérica vascular $\left(\mathrm{N}_{\mathrm{v}(\text { vasc })}\right)$, número total de vasos no órgão $\left(\mathrm{N}_{\text {(vasc) }}\right)$, do timo em fetos fêmeas nos diferentes grupos etários - São Paulo - 2007

Tabela 4 Valores das variáveis densidade de comprimento do vaso (Lv), comprimento do vaso (L), densidade de superfície de área (Sv), superfície de área (S), estimação da densidade numérica vascular $\left(\mathrm{N}_{\mathrm{v}(\text { vasc })}\right)$, número total de vasos no órgão $\left(\mathrm{N}_{\text {(vasc) }}\right)$, do timo em fetos machos nos diferentes grupos etários - São Paulo - 2007 


\section{SUMÁRIO}

1 INTRODUÇÃO

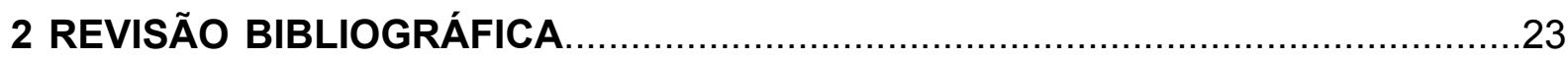

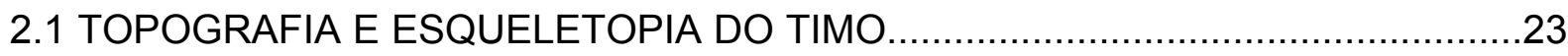

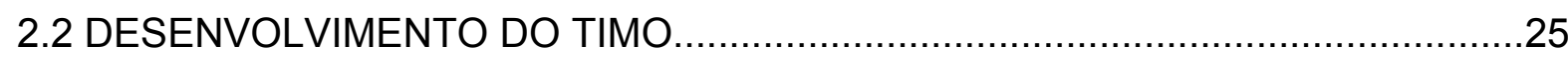

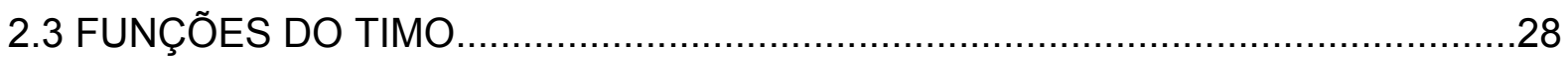

2.4 HISTOLOGIA

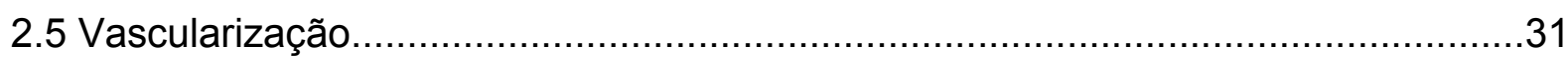

2.6 Influência do sistema nervoso autônomo (SNA).................................................33

2.7 Origem dos linfócitos e diferenciação dos linfócitos T..........................................35

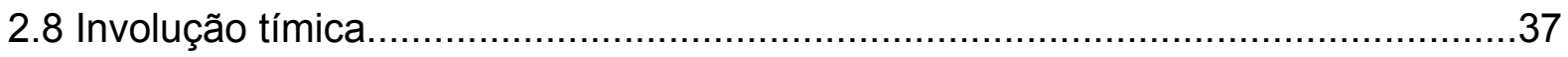

2.9 Timectomia

3 MATERIAL E MÉTODO

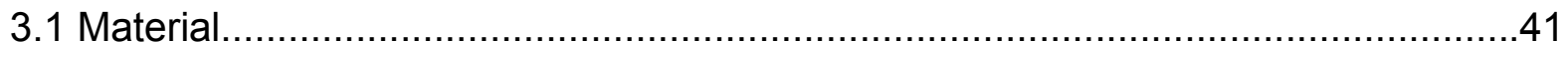

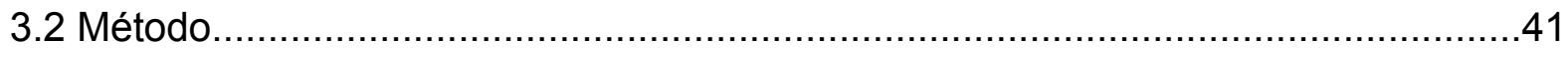

3.2.1 Lavagem do sistema circulatório e fixação do timo por meio de

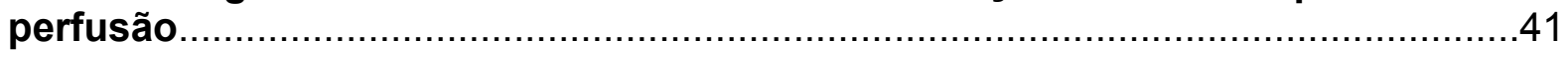

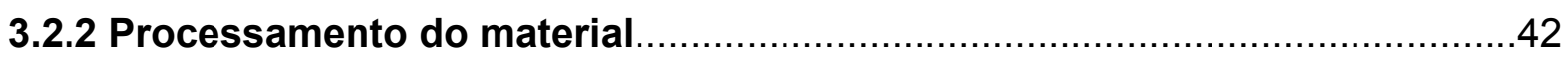

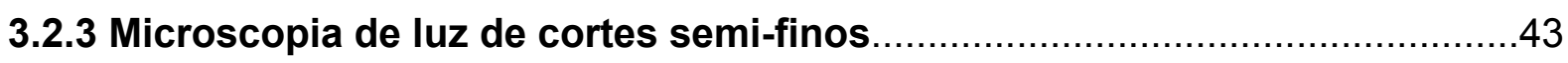

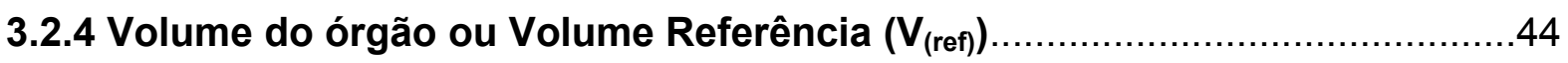

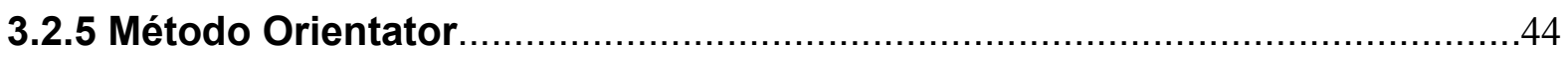

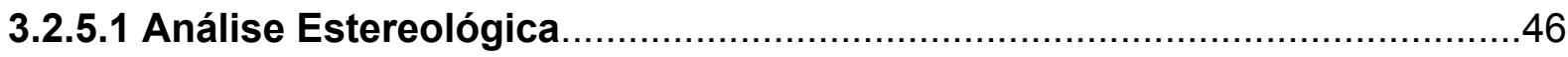

5.2.6.1 Método Disector Físico...........................................................................

5.2.6.2 Determinação do Número de Euler no Método de Disector..............................49 


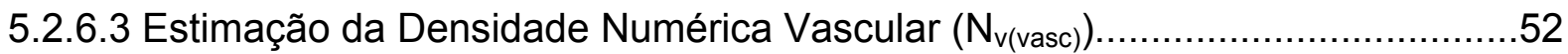

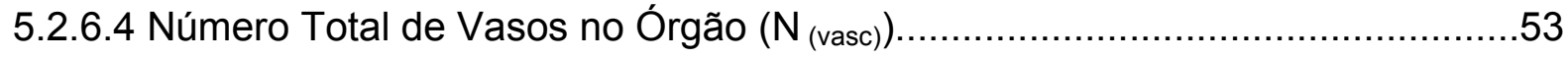

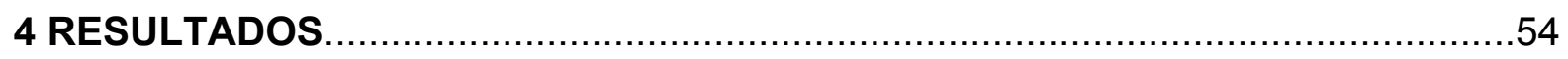

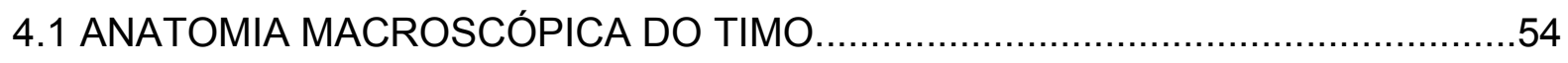

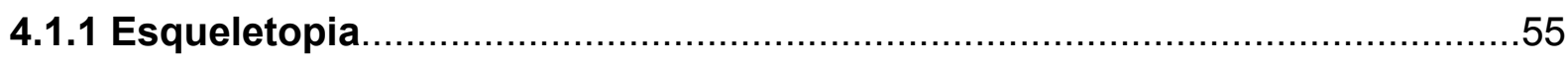

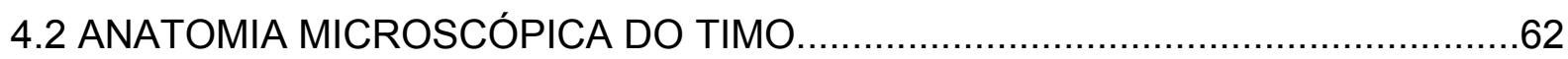

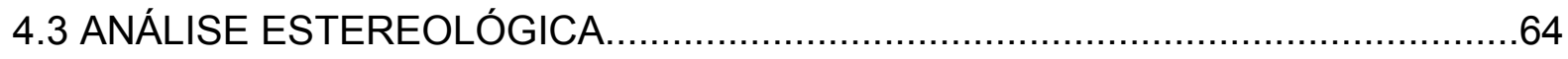

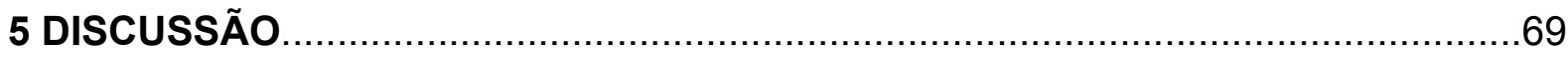

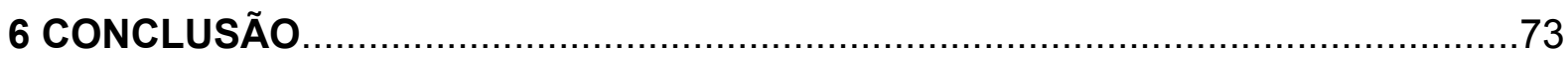

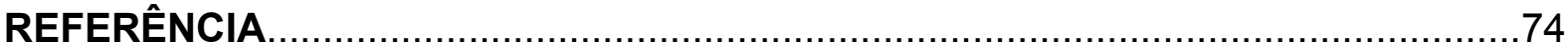




\section{INTRODUÇÃO}

A disposição arquitetônica da vascularização tímica e dos vasos linfáticos em animais de laboratório e em humanos tem sido objeto de intenso esforço investigativo, isto não somente é importante para um entendimento correto comportamento vascular como para a relação do funcionamento do órgão e sua importância no organismo do indivíduo.

No passado, ao timo eram atribuídas várias funções, inclusive a de secreção do "elixir da vida" e da "juventude eterna". Sua relação com a produção de linfócitos foi primeiro reconhecida no século XVIII por Thomas Hewson e Magnus Falconer. Eles propuseram que o timo era uma glândula que secretava um fluido contendo numerosas partículas sólidas pequenas, similares àquelas encontradas nos linfonodos, e "que os vasos linfáticos do timo transportam o fluido secretado pelo ducto torácico para os vasos sangüíneos" (RITTER; CRISPE, 1992).

O timo é um órgão linfático primário que desenvolve sua atividade em organismos jovens (KÖNIG; LIEBICH, 2004). As células T iniciam seu desenvolvimento como precursoras na medula óssea. Essas células migram para o timo, onde sofrem divisão, diferenciação e maturação em células T funcionais (BAR-DAYAN et al., 1999). A migração para os órgãos linfáticos secundários faz com que adquiram características novas e se transformem em células imunocompetentes (SILVA et al., 2001). O movimento dos timócitos, através das vênulas pós-capilares para os órgãos secundários denominada periferialização, é um aspecto significante da imunidade mediada por células (BANKS, 1992).

O desenvolvimento do timo ocorre de forma par desde o terceiro arco faríngeo, ao longo da traquéia em direção caudal, até o pericárdio (KÖNIG; LIEBICH, 2004). O timo deriva-se da terceira e da quarta bolsas faríngeas acompanhando os derivados paratireoideanos dessas mesmas bolsas. O broto tímico se separa dos derivados da paratireóide, ocupa parte do mediastino cranial, da entrada do tórax e da região cervical ventral (BANKS, 1992).

Diversos experimentos têm revelado que o desenvolvimento normal, a 
manutenção dessas estruturas linfóides, são dependentes de um órgão linfóide específico quanto ao caráter precursor linfopoiético - o timo. Assim como, as respostas imunológicas naturais ou induzidas que estão de diferentes formas relacionadas às estruturas do sistema linfático, muitas vezes são intermediadas e coordenadas pelo timo (BOMBONATO, 1997; APPOLINÁRIO, 1998).

Ainda na vida fetal e no período neonatal o timo é o órgão com maior importância imunológica e, anatomicamente, é o maior órgão linfático. Dentre os órgãos linfóides, é ele que possui a maior atividade linfopoiética constando como precursor da linfopoese (DRUMMOND,1996) demonstrando também relações com o sistema endócrino, principalmente com a função gonadal (DRUMMOND,1996; APPOLINÁRIO, 1998).

Após a maturidade sexual do animal o órgão sofre marcada involução (BANKS, 1992; KÖNIG; LIEBICH, 2004), com variações conforme a espécie animal (KÖNIG; LIEBICH, 2004).

A involução gradual e contínua do timo é caracterizada pela diminuição do peso do órgão, perda dos linfócitos corticais, infiltração pelas células adiposas e aumento do número dos corpúsculos tímicos. Por fim, a infiltração de células adiposas substitui completamente o órgão (BANKS, 1992).

O envelhecimento é considerado como inevitável parece natural que com o crescimento do indivíduo vários órgãos começam a falhar. No entanto, não é totalmente claro porque a senescência deve ocorrer e deve haver uma razão do porque um órgão não mantém sua função indefinidamente. O timo é um exemplo, sendo um órgão que é submetido à senescência prematura; devido ao seu papel central no desenvolvimento imunológico, é importante conhecer o porquê (GEORGE; RITTER, 1996).

O desenvolvimento da imunocompetência depende da diferenciação dos linfócitos do timo, que são capazes de reativar células imunes mediadas, em adição à diferenciação em outros locais de células que sintetizam e secretam anticorpos. A deficiência imune é resultado do não desenvolvimento de um ou ambos os processos (BOCKMAN, 1997).

O papel significativo do timo na imunidade é facilmente demonstrado, em algumas espécies, pela timectomia neonatal, causando o enfraquecimento da reação de hipersensibilidade retardada. A habilidade para produzir respostas mediadas por 
anticorpos também fica prejudicada, uma vez que a produção de anticorpos requer a colaboração de células T (BANKS, 1992).

Apesar de a função tímica ser responsabilizada por mecanismos fundamentais na aquisição das defesas e conseqüentes respostas orgânicas, ela ainda não é totalmente esclarecida, tampouco as bases morfológicas que respondem por tais funções, como o processo de desenvolvimento e involução que estão por serem respondidos (BOMBONATO, 1997).

Morfologistas estão tradicionalmente interessados na forma e composição de estruturas macro, meso, microscópico e ultraestrutural. Recentemente, morfologistas tem se beneficiado do uso de técnicas genéticas e moleculares que ajudam no esclarecimento de dúvidas com isso melhorando as pesquisas biológicas e biomédicas. No entanto, questões concernentes a alterações de tecidos, células ou organelas celulares (as quais frequentemente aparecem em períodos de adaptação, evolução ou doença de um organismo), assim como uma melhor correlação entre morfologia e função, necessitam de uma análise quantitativa para melhor entendimento (MAYHEW, 1992; MANDARIM, 2003; ANDERSEN; PAKKENBERG, 2003).

Estudos estereológicos são cada vez mais freqüentes na literatura principalmente nos campos do desenvolvimento, evolução, patologia e neurociências. $O$ desafio da estereologia é interpretar o arranjo tridimensional interno com base na análise de cortes da estrutura que mostram apenas uma informação bidimensional, tendo como princípio considerações geométricas e probabilidade estatística (WEIBEL, 1979; JENSEN, 1998; MANDARIM, 2003).

A estereologia tem vantagens sobre os estudos qualitativos. Os resultados são numéricos, não subjetivos. A comparação entre diferentes grupos como idade, espécies, ação de drogas, manipulação, são facilmente realizadas.

O timo por se tratar do principal órgão responsável pela imunidade celular, cuja presença e atividade são fundamentais para o crescimento de um animal sadio, vem sendo objeto de estudos por alguns pesquisadores.

Com respeito à irrigação do timo, vários autores se reportam de maneira genérica, principalmente para os animais domésticos. Portanto, a realização deste 
trabalho, para contribuir e favorecer o entendimento da irrigação tímica, assim como ajudar na elucidação do processo de involução fisiológica do timo em gatos.

O objetivo do trabalho é estudar quantitativamente, aspectos da vascularização do timo, principalmente aqueles relativos à densidade e comprimento vascular, quantidade numérica dos vasos e, estabelecer se há diferenças entre as idades e entre os sexos, quanto à morfologia e os dados estereológicos. 


\section{REVISÃO DE LITERATURA}

Com o propósito de oferecermos um melhor entendimento, compilamos e apresentamos as informações propostas pelos tratadistas e trabalhos específicos concernentes ao timo.

\subsection{TOPOGRAFIA E ESQUELETOPIA DO TIMO}

O timo é encontrado no espaço mediastinal cranial. Entretanto, nos cavalos, vacas, carneiros, porcos e galinhas ele se estende pelo pescoço até a altura da glândula tireóide. O tamanho do timo pode variar consideravelmente, sendo que seu tamanho relativo máximo ocorre em animais recém-nascidos, e seu tamanho absoluto máximo durante a puberdade (TIZARD, 2000).

Em gatos o timo ocupa a região de mediastino cranial ao coração e ventral a traquéia (Figura 1). Variando em tamanho com a idade do gato, no neonato é maior e atinge o seu tamanho absoluto na puberdade. Em filhotes, se estende cranialmente à região torácica e caudalmente entre as veias braquiocefálica em nível de quinta e sexta cartilagem intercostal, onde repousa na superfície ventral do pericárdio. A região caudal possui o lóbulo direito menor que o esquerdo (HUDSON; HAMILTON,1993). 


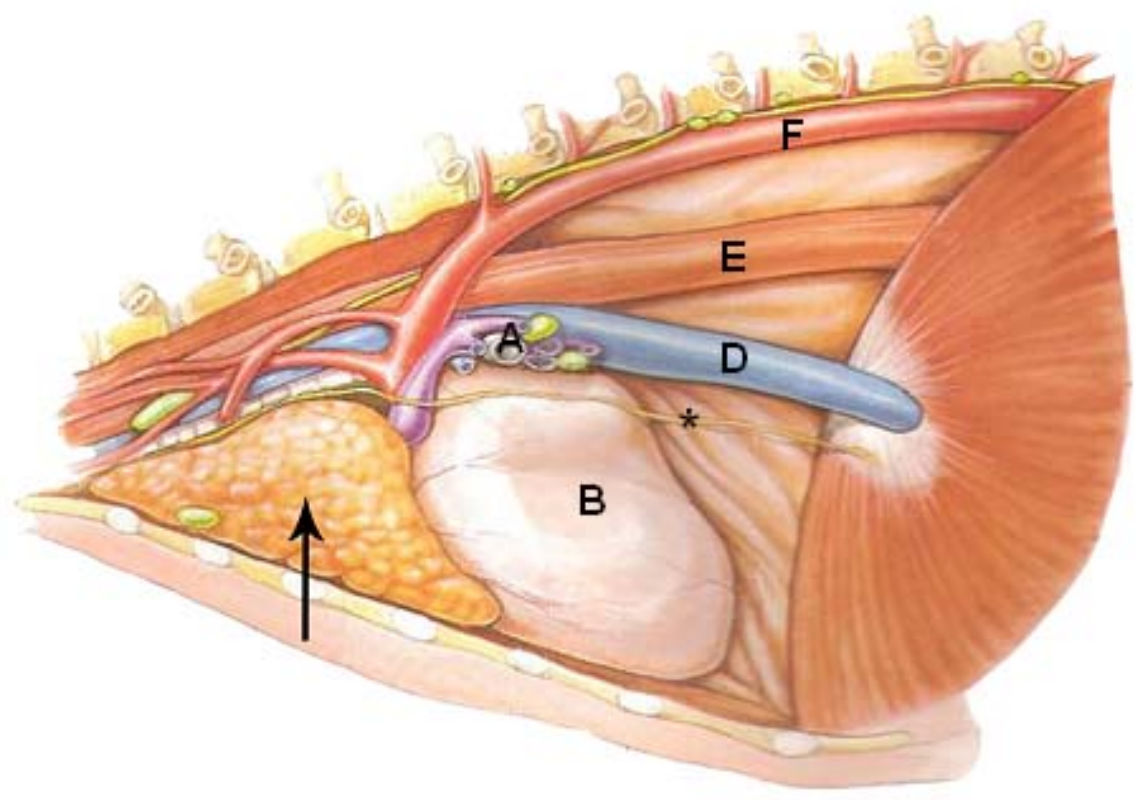

Figura 1 - Ilustração demonstra a cavidade torácica de gato com os pulmões seccionados. Timo (seta preta); A: brônquios seccionados e vasos pulmonares; B: coração com pericárdio; C: nervo frênico; $D$ : veia cava caudal; E: esôfago; F: aorta. (Fonte: Hudson; Hamilton, 1993)

Daschinger (1983) descreveu o timo, do gato doméstico recém-nascido, macroscopicamente como um órgão visivelmente lobular e de coloração rosa-pálida. E que se estende cranialmente do manúbrio esternal pela abertura torácica cranial e ventralmente preenche dois terços do mediastino cranial. Observou também que o timo do gato possui uma porção par, pequena e comum em região cervical.

A forma deste órgão em gatos varia individualmente, mesmo entre irmãos e irmãs, muitas vezes consideravelmente (DASCHINGER, 1983).

Segundo Silva et al. (2001) a topografia do timo, em seu trabalho realizado em gatos, demonstrou a presença de duas porções torácica e cervical, onde esta última, quando presente mostrou-se fina e estreita, representando não mais que um quinto a um sexto do tecido tímico total, e pronunciou-se cranialmente ao primeiro par de costelas. 
$\mathrm{Na}$ superfície lateral da porção torácica esquerda mais dorsalmente e mais a esquerda localiza-se o nervo frênico. Caudalmente após a borda dorsal livre corre o nervo vago, mais à esquerda medialmente ao nervo vago, encontra-se o tronco braquiocefálico e a artéria subclávia esquerda. Dorsolateralmente a região esquerda da porção torácica está encoberta pelo lobo cranial do pulmão esquerdo (DASCHINGER, 1983).

A porção torácica direita é caracterizada como sendo uma porção menor e aproximadamente de formato triangular. Sua margem cranioventral convexa corre com A. torácica interna direita, a margem caudal côncava se encontra sobre o saco cranial do coração. Dorsal a porção é limitada pela V. cava cranial e o N. frênico mais à direita. Lateralmente a porção direita da porção torácica é completamente coberta pelo pulmão torácico direito (DASCHINGER, 1983).

A transição da porção torácica para a porção cervical é demarcada por sulcos que são sobrepostos lateralmente por parênquima da porção torácica. Nestes sulcos encontram-se a A. e V. torácica interna descendente direita e a esquerda ventral ao esterno (DASCHINGER, 1983).

Após as duas porções torácicas craniais, surge a porção cervical que se inicia do terceiro par de costelas e avança cranialmente pela abertura torácica cranial, dorsalmente localiza-se a traquéia (DASCHINGER, 1983).

Em um trabalho realizado por Bombonato et al. (2001) com fetos de caprinos da raça Saanen foi observado a morfologia, topografia e esqueletopia do timo. Partindo da parte torácica observaram o timo como uma massa única, de aspecto lobulado, com forma de trapézio irregular, envolvendo dorsalmente e, em parte, a face lateral esquerda do tronco braquiocefálico e ventralmente no limite deste tronco, preenchendo o espaço mediastinal cranial em sua porção pré-cardíaca, sobrepondo-se a uma porção do lobo cranial do pulmão esquerdo. Caudalmente observaram uma relação com a margem cranial do coração na sua face esquerda, sem, no entanto, cobri-la, e cranialmente alcança a transição cérvico-torácica, mantendo relação com a face interna do primeiro par de costelas e a artéria torácica interna esquerda. Em relação à projeção do timo ao gradil costal, especialmente à esquerda, devido a sua acentuada assimetria para este antímero, notaram que cranialmente, o limite deste se faz, em todos os casos, 
na altura da margem caudal do $1^{\circ}$ par de costelas e caudalmente atinge a margem cranial do $3^{\circ}$ ou $4^{\circ}$ par de costelas.

Segundo um trabalho realizado por Agreste (2005) em fetos de cães foi descrito o timo como um órgão de coloração rósea com discretas lobulações nos filhotes, localizado no espaço mediastínico cranial, entre os dois pulmões, e sua extremidade caudal é moldado na superfície cranial do pericárdio, apresenta apenas parte torácica, sendo esta dividida incompletamente em um largo lobo direito e um pequeno lobo esquerdo, seu pólo cranial se localiza abaixo da traquéia e estende-se além do primeiro par de costelas.

A porção cervical do timo tipicamente se atrofia dentre os primeiros poucos meses de vida no cavalo, e, no entanto, não é comumente encontrada exceto no jovem potro. Ao contrário, o timo do bovino e identificável, mesmo no adulto, como uma estrutura pálida e lobulada. Os lobos cervicais direito e esquerdo são bem desenvolvidos em bezerros, e o timo é às vezes removido no abatedouro como "pão doce". O timo do porco é também muito desenvolvido até a idade de abate aproximadamente seis meses (SMALLWOOD, 1992).

\subsection{DESENVOLVIMENTO DO TIMO}

O epitélio do timo é derivado da camada endodérmica embrionária, com possível contribuição do ectoderma, por uma série de fases de diferenciação, cada qual deve ser completada com o objetivo de proporcionar um microambiente ótimo para o desenvolvimento e função tímica (BOCKMAN,1997).

Para Holländer et al.,(2006), a organogênese inicial do timo está intimamente ligada ao da glândula paratireóide, a qual tem sua origem na porção dorsal da terceira bolsa faríngea. Inicialmente formada como um primórdio comum, uma partição espacial está presente entre esses dois órgãos durante esta porção de suas organogêneses. $O$ primeiro pensamento é que o timo é constituído de células epiteliais que tem origem endodermal e ectodermal, experimentos em sistema aviário e mais recentemente em 
camundongos demonstraram claramente que as células do timo são de origem somente endodermal e que as células epiteliais ectodermais não contribuem para o desenvolvimento do timo.

O timo é um órgão epitélio linfóide formado da terceira e quarta bolsa faríngea descendendo pelo tórax durante o desenvolvimento fetal. As suas células epiteliais formam uma base (forro) onde os linfócitos podem amadurecer e desenvolver. Ainda há alguma confusão na ordem precisa dos eventos, mas parece que linfócitos derivados da medula óssea são atraídos pelo timo em desenvolvimento, qual está sobre a influência de um fator (ou fatores) tipo hormonal solúvel, um dos quais tem sido denominado timosina. As células que colonizam o timo não possuem características de células $B$ nem de células $T$. No entanto, dentro de várias horas da chegada ao timo, os linfócitos, começam a expressar uma série de antígenos de superfície e receptores de uma maneira ordenada, conduzida por fatores solúveis liberados por células de suporte do timo (HALLIWELL; GORMAN, 1989).

A porção significante de diferenciação do intestino anterior que segue com o objetivo de compreender o desenvolvimento do timo é a região faríngea. A faringe embriônica é importante para origem de muitos órgãos, incluindo as glândulas tireóide e paratireóide assim como o timo. Um entendimento desta associação íntima durante o desenvolvimento inicial é útil no entendimento de algumas deficiências que são observadas em associação com desenvolvimento de defeitos tímicos (BOCKMAN,1997).

A proliferação das células que formam a terceira bolsa faríngea de cada lado produz acumulo de epitélio que se estende ao mesênquima circundante. A porção dorsal de cada terceira bolsa faríngea se espessa em uma massa sólida que se torna a glândula paratireóide. As células remanescentes constituem o primórdio epitelial do timo. A terceira bolsa ventral é inicialmente uma cavidade, mas com o desenvolvimento conduz sua separação com a cavidade faríngea, e um corpo sólido é formado enquanto migra ventralmente e caudalmente (BOCKMAN,1997).

Durante o desenvolvimento do timo, ramos vasculares sangüíneos penetram no parênquima profundo acompanhando os tecidos conjuntivos da cápsula e formam um 
espaço de tecido conjuntivo perivascular (compartimento extraparenquimal) ao redor das veias (KATO, 1997).

Segundo Silva et al. (2001) o timo apresenta seu mais lato grau de desenvolvimento durante a última fase do período pré-natal e no início de vida pósnatal.

\subsection{FUNÇÕES DO TIMO}

O sistema linfóide é composto de órgãos linfóides primários e secundários. A função da estrutura linfóide primária é a linfopoiese das linhagens de células B e T. Os órgãos linfóides primários são constituídos pela medula óssea, timo, e o fígado fetal. Em aves, a Bursa de Fabricius é o local de linfopoiese de células B. Os órgãos linfáticos secundários são os nódulos linfáticos, baço, e estruturas linfóides associadas com a superfície de mucosas e pele (HALLIWELL; GORMAN, 1989).

O timo é um órgão epitéliolinfóide formado da terceira e quarta bolsa faríngea que se estende até o tórax durante o desenvolvimento fetal (HALLIWELL; GORMAN, 1989). Em condições normais, uma barreira antigênica fisiológica previne antígenos, localizando e estimulando uma resposta imune no timo. Certas doenças tais como a cinomose canina, o antígeno viral tem acesso ao tecido tímico e, na fase de recuperação de infecção, podem estimular a formação de um centro germinal na medula (GERSHWIN; KRAKOWA; OLSEN, 1995).

A função do timo é educar e provir à circulação e os órgãos linfóides secundários de linfócitos T. Aos 40 dias de gestação em gatas prenhes, os linfócitos povoam o timo, onde desenvolvem a capacidade de distinguir o próprio do não próprio. Os órgãos linfóides secundários acolhem os linfócitos $\mathrm{T}$ funcionais, em gatos isto ocorre antes do nascimento (HUDSON; HAMILTON, 1993).

O timo é capaz de secretar hormônios e funcionar como uma glândula endócrina. As células epiteliais tímicas liberam vários hormônios polipeptídicos que devem restaurar parcialmente a função tímica. Eles incluem as moléculas, chamadas de 
timosinas, timopoietinas, fator humoral tímico, timulina e timoestimulantes. Os mais importantes são a timosina que age sobre a medula óssea fazendo com que células precursoras ali localizadas adquiram algumas características de célula $\mathrm{T}$, as timopoietinas que provocam a diferenciação de células precursoras de células $T$ e estimulam a função de células $\mathrm{T}$ e o fator tímico humoral e a timulina que restauram parcialmente a função de células $T$ em animais timectomizados (TIZARD, 1985; TIZARD, 2000).

Em um trabalho realizado por Li et al. em 2002, em camundongos infectados com Hepatite viral tipo $B$, provaram que o hormônio tímico denominado Timosina $\alpha 1$ sintetizada quimicamente reabastece a produção de anticorpo mediada por célula $\mathrm{T}$ e acelera o restabelecimento e maturação dos timócitos e concluíram que o restabelecimento de alguns dos defeitos no sistema de defesa do hospedeiro facilita a eliminação do agente infeccioso.

\subsection{HISTOLOGIA}

O timo tem origem embrionária dupla enquanto que os outros órgãos linfóides possuem origem somente mesodérmica. Seus linfócitos formam-se a partir de células mesenquimatosas, que invadem um espaço epitelial derivado do endoderma da terceira e, algumas vezes também da quarta bolsa faríngea (JUNQUEIRA; CARNEIRO, 1999).

Os elementos estromais de origem mesodérmica são capilares, septos e espaços perivasculares. Esses elementos separam o timo em pseudolóbulos. O espaço epitelial do timo e os espaços perivasculares estão sempre separados, um do outro por uma íntima camada celular epitelial, com uma lâmina basal que contribui para a barreira hematotímica (VON GAUDECKER, 1990).

O órgão é revestido por uma cápsula de tecido conjuntivo frouxo e tecido adiposo (MELO; LAGE, 1987; BANKS, 1992) do qual partem septos de tecido semelhantes, subdividindo o órgão em lóbulos. Esses septos se estendem para a junção corticomedular (BANKS, 1992). 
O tecido conjuntivo, que constitui esta cápsula apresenta uma preponderância de fibras colágenas sobre fibras elásticas e tanto umas como outras podem surgir em quantidade aumentada, formando espessamentos, em pontos de junção da cápsula com a veia jugular ou outros vasos (MELO; LAGE, 1987).

O parênquima de cada lóbulo está subdividido em lóbulos que variam em tamanho, dependendo da espécie, de 5 a $15 \mathrm{~mm}$ de largura. O tecido intersticial do parênquima contém poucas fibras de tecido conjuntivo reticular, muitas das quais podem estar concentradas ao redor dos vasos sangüíneos (GETTY, 1986).

O órgão é formado pelo córtex e pela medula bem definidos (BANKS, 1992). A parte mais externa de cada lóbulo, o córtex, é densamente infiltrada por linfócitos pequenos denominados timócitos. Os timócitos na medula não são tão densamente agrupados como no córtex, portanto, as células da medula são claramente visíveis (BANKS, 1992; TIZARD, 2000)

Investigações anteriores demonstraram a presença de vasos linfáticos na cápsula e no tecido conectivo interlobular. Em timo de camundongo foi registrado que os vasos linfáticos acompanham os vasos sangüíneos (ODAKA et al., 2006).

Em um trabalho realizado por Odaka et al. (2006), os pesquisadores realizaram análise de imunofluorescência da expressão de marcadores de vasos linfáticos com o objetivo de examinar a distribuição dos vasos linfáticos no timo de camundongos normais e concluíram que há a presença de capilares linfáticos por todo o timo.

Os vasos linfáticos são adaptados para carrear fluido, lipídios, e macromoléculas. Eles também servem como caminho de transito de linfócitos e células apresentadoras de antígenos, tais como células dendríticas. Comparados com os vasos sangüíneos, os vasos linfáticos podem ser morfologicamente idênticos pela presença de uma única camada fina celular endotelial não-fenestrada, a qual não possui células musculares lisas (ODAKA et al., 2006).

A característica definitiva do órgão é a presença de corpúsculos tímicos denominados corpúsculos de Hassall, os quais estão presentes na medula. Sua função é desconhecida e são observados com freqüência nos estágios avançados de involução do timo (BANKS, 1992). 
Os corpúsculos de Hassal consistem de poucas camadas de células epiteliais dispostas concentricamente, em seu interior, estas células epiteliais estão mortas, normalmente a porção central consiste de queratina e material hialino (GETTY, 1986).

\subsection{VASCULARIZAÇÃO}

Durante o desenvolvimento do timo, ramos sangüíneos penetram no interior do parênquima acompanhando o tecido conjuntivo derivado da cápsula formando um espaço de tecido conjuntivo perivascular ao redor das veias (KATO, 1997).

As artérias penetram no timo pela cápsula, ramificam-se e aprofundam-se no órgão, seguindo os septos conjuntivos, originando as arteríolas que penetram no parênquima seguindo os limites entre a cortical e a medular. Estas arteríolas formam capilares que entram na cortical, ramificam-se e anastomosam-se e depois descrevem um arco, dirigindo-se para a região medular, onde desembocam em vênulas. A região medular recebe outros capilares diretamente das arteríolas do limite córtico-medular. As vênulas da medular confluem para formar veias que penetram nos septos conjuntivos e saem do timo pela cápsula do órgão (JUNQUEIRA; CARNEIRO, 1999).

A irrigação do timo apresenta características peculiares, onde os capilares e pequenos vasos destinados ao órgão apresentam uma membrana basal, envolvida por uma camada de células epiteliais, que apesar de não ser totalmente contínua, atua como uma barreira; dificultando a passagem de antígenos ou macromoléculas do sangue para o interior do parênquima e, conseqüentemente, o seu contato com os linfócitos do órgão (SILVA et al., 2001). Esta barreira hematotímica que separa o sangue do parênquima tímico existe na região cortical do timo, e não na medular, e deve-se principalmente às junções oclusivas entre as células endoteliais não fenestradas dos capilares (JUN QUEIRA; CARNEIRO, 1999).

Daschinger em 1983 descreveu que o suprimento arterial de todo o timo de gatos recém-nascidos provem da $A$. torácica interna direita que se ramifica dando origem a 
um ramo caudal em direção ao timo torácico e um ramo craniomedial para o timo cervical.

Scala, Langella e Budetta (1984) após estudo do timo de patos domésticos evidenciaram as artérias lobares originando-se diretamente da artéria comum do nervo vago, correspondendo aos lobos tímicos, penetrando em número de uma a duas por lobo. Observaram também que a vascularização do órgão apresenta características particulares devido à morfologia caracterizando os lobos como uma entidade anatômica isolada e com uma topografia peculiar ocupando juntos, uma grande extensão da região cervical.

Com respeito às artérias tímicas, somente Versari (1897) descreveu as artérias tímicas inferior e média no homem e em outros mamíferos. Notou que não encontrou a artéria tímica surgindo da artéria carótida comum externa ou interna, embora o ramo descendente da artéria tireóidea superior vascularize a traquéia e o esôfago.

Segundo trabalho realizado por Bombonato et al. (2001), o timo como um todo recebe irrigação de vasos oriundos do tronco braquiocefálico, tronco bicarotídeo, artérias intercostais esquerdas, torácica interna esquerda, escapular dorsal esquerda, de ramos diretos e indiretos das artérias carótidas comuns esquerda e direita, das artérias tireóideas craniais e caudais esquerda e direita, tireóideas imas esquerda e direita, laríngeas esquerda e direita, faciais esquerda e direita, axilar esquerda e carótida externa esquerda.

Silva et al. (2001) observaram em seu trabalho realizado em gatos, SRD, adultos, ambos os sexos, que a maior contribuição vascular se deu através dos ramos fornecidos pela artéria torácica interna esquerda e do tronco braquiocefálico. E concluíram que os ramos diretos destinados ao timo foram provenientes das artérias torácicas internas e carótidas comuns direita e esquerda e dos troncos braquiocefálico e bicarotídico.

Em um trabalho realizado por Olson e Poste (1973), foi estudado o suprimento sanguíneo do timo de porquinhos da índia e porcos utilizando carbono ou prata intravascular demonstrando que estes animais possuem um sistema vascular mais extensivo que o do camundongo. Histologicamente em seções seriadas as artérias interlobulares foram vistas entrando a junção medular de dois ou mais lobos e se 
subdivide em um número grande de ramos menores. Esses atravessam a medula ou correm ao longo da junção corticomedular. Elas então se angulam de repente para dentro do córtex como fileiras paralelas, vasos de parede fina. Esses vasos que penetram às vezes se ramificam e variam de diâmetro, muitas vezes se tornam grandes vênulas antes de confluírem para o sistema de veias perilobulares descrito acima. Observaram também que uma rede de veias ao longo da junção corticomedular a qual é acompanhada por artérias medulares.

Em um trabalho realizado por Agreste (2005) foi feito um estudo esterológico do timo em cães onde foram avaliados os aspectos quantitativos vasculares deste órgão e seus achados foram que o timo das fêmeas apresentou maior volume (Vref) e dimensões de tamanho que os machos; a densidade numérica vascular e o número total de vasos foram menores nos machos do que nas fêmeas. E que as variáveis estereológicas e as variáveis, comprimento, espessura e largura tiveram aumento gradativo de acordo com as faixas etárias, sendo que nas fêmeas os valores eram maiores do que nos machos, com exceção da densidade de comprimento (Lv).

\subsection{INFLUÊNCIA DO SISTEMA NERVOSO AUTÔNOMO (SNA)}

Muitas interações que ocorrem entre o microambiente celular e o desenvolvimento de células $T$ acontecem sobre a influência do sistema nervoso autônomo e pelo controle neuroendócrino (SAVINO; DARDENNE, 2000; SOLAROVIĆ; LALIĆ; LEPOSAVIĆ, 2004).

Órgãos linfóides, assim como os vasos sangüíneos, são inervados predominantemente pela divisão simpática do sistema nervoso autônomo. Fibras de nervos pós-ganglionares noradrenérgicos adentram o timo acompanhando os grandes vasos sangüíneos (SOLAROVIĆ; LALIĆ; LEPOSAVIĆ, 2004; LEPOSAVIĆ; PLEĆǍ̌; KOSEC, 2000) e a maioria das fibras está localizada ao redor da vasculatura (VIZI et al., 1995). 
A inervação noradrenérgica do parênquima tímico é restrito principalmente ao córtex, e somente, perfis nervosos escassos tem sido observados em região medular (VIZI et al., 1995) e estão próximos as células epiteliais tímicas (LEPOSAVIĆ; PLEĆAŠ; KOSEC, 2000). Perfis nervosos noradrenérgicos com uma densidade pronunciada foram observados no subcompartimento cortical periférico e nas junções corticomedulares. Esses nervos foram encontrados nas proximidades dos timócitos e das células não-linfóides tímicas. Além disso, foi demonstrado que os $\beta$-adrenoreceptores são expressos nos timócitos e nas células não-linfóides tímicas (SOLAROVIĆ; LALIĆ; LEPOSAVIĆ, 2004) como mastócitos, macrófagos e células epiteliais (LEPOSAVIĆ; PLEĆAŠ; KOSEC, 2000). Sugerindo que a noradrenalina das fibras simpáticas pode atuar como neurotransmissor nos nervos terminais conectando os timócitos corticais e as células epiteliais medulares, e como um modulador parácrino disponível aos receptores nas células tímicas.

Em um trabalho realizado por Solarović, Lalić e Leposavić (2004) demonstrou que ratos Wistar machos imaturos tratados por 15 dias com propranolol produziram bloqueio dos $\beta$-adrenoreceptores afetando o tamanho do timo e suas estruturas, levando a uma diminuição da celularidade do córtex e medula tímica, achados que concordam com Leposavić, Plećaš e Kosec (2000). Levando em consideração o tamanho do timo no inicio do tratamento (21 dias pó-natal) e no controle com injeção salina (36 dias pós-natal), parece que o bloqueio dos receptores $\beta$-adrenérgicos durante este período de desenvolvimento acarretou uma diminuição do crescimento tímico e/ou aceleração do processo de involução (entre o $21^{\circ}$ e $36^{\circ}$ dia). Tem sido demonstrado que o timo de ratos atinge seu tamanho máximo na puberdade, e depois se inicia a involução lentamente (MARCHETTI; MORALE; PALLETIER, 1990).

Mudanças no tamanho do timo na puberdade podem estar relacionadas com alterações hormonais (OLSEN; KOVAC,1996). Estes achados condizem com a hipótese de que o sistema nervoso simpático está envolvido com a responsividade da célula tímica a ação hormonal via mudanças de densidade de receptor dentro da glândula tímica. Deve ser adicionado a esta hipótese que os hormônios esteróides sexuais influenciam a expressão de receptores $\beta$-adrenérgicos nas células linfóides, assim 
como mudanças nas alterações dos hormônios relacionados à maturação do eixo hipotálamo-pituitário-gonadal (MARCHETTI; MORALE; PALLETIER,1990).

A redução da população de timócitos em ratos tratados com propranolol pode estar relacionada com o desbalanço da taxa de proliferação de timócitos e apoptose, processo conhecido por ser influenciado por catecolaminas. E como a estimulação simpática ou administração de catecolaminas aumenta a saída de células da medula óssea, baço e linfonodos, os animais tratados com propranolol obtiveram uma redução da saída das células precursoras de linfócitos da medula óssea, contribuindo também para a diminuição da população de timócitos (SOLAROVIĆ; LALIĆ; LEPOSAVIĆ, 2004).

Em um trabalho realizado por Vizi et al. em 1995, eles investigaram se a noradrenalina (NA) é um transmissor de sinal entre a inervação simpática e os timócitos, concluíram que em ratos jovens o córtex tímico é inervado por terminais nervosos catecolaminérgicos/noradrenérgicos. A liberação da NA dos terminais nervoso simpáticos é sob inibição da NA liberada endogenamente pelos $\alpha_{2}$-adrenoreceptores pré-sinápticos. A noradrenalina liberada não-sinapticamente se difunde ao parênquima e é capaz de transmitir um sinal para a membrana dos timócitos por modulação de canais de potássio. A NA liberada no timo possui importância fisiológica e patológica durante estresse e respostas inflamatória e imunológica.

Vários hormônios e citocinas são reconhecidos atualmente como potentes moduladores da fisiologia dos timócitos, é uma questão de especulação, é tentador sugerir que as catecolaminas liberadas localmente no timo podem estar envolvidas na sintonização das respostas dos timócitos aos sinais regulatórios de citocinas e hormônios liberados de origem sangüínea ou local (VIZI et al., 1995).

\subsection{ORIGEM DOS LINFÓCITOS E DIFERENCIAÇÃO DOS LINFÓCITOS T}

O timo é o único órgão hematopoiético que recruta células precursoras hematopoiéticas do sangue e, ao mesmo tempo, exclui células maduras de entrarem no timo. Este recrutamento é contínuo pelo timo não suportar células-tronco 
hematopoiéticas de auto-renovação. O requerimento para importação contínua de precursores hematopoiéticos e o processo de diferenciação intratímico de célula $T$ estão intrinsecamente ligados ao processo de desenvolvimento do timo (BOEHM; BLEUL, 2006).

As células $\mathrm{T}$ iniciam seu desenvolvimento como precursoras na medula óssea. Essas células migram para o timo, onde se dividem se diferenciam, e se maturam em células T funcionais. A maioria dos timócitos (95-99\%) morre no curso deste processo, e somente poucos deixam o timo como células maduras (BAR- DAYAN et al.,1999).

As células $T$ são derivadas de precursores hematopoiéticos, os quais, após entrarem no timo, são submetidos a um programa de proliferação, diferenciação, e seleção para produzirem uma população de células $T$ funcionalmente competentes (ANDERSON et al.,1996). No camundongo, colonização inicial do timo rudimentar por precursores do fígado fetal é iniciada aproximadamente no $11^{\circ}$ dia de gestação (OWEN; RITTER, 1969). Durante a colonização inicial, a qual precede a vascularização, os precursores dos vasos deixam os vasos faringeais adjacentes e cruzam o mesênquima peritímico e a membrana basal que circunda o epitélio rudimentar para adentrar ao timo (WILKINSON; OWEN; JENKINSON, 1999).

A diferenciação dessas células ocorre ao longo de sua migração no microambiente estritamente compartimentalizado tímico, que é formado de células de diferentes tipos como células epiteliais, macrófagos, células dendríticas, fibroblastos, e componentes da matrix extracelular, e o processo de desenvolvimento das células $\mathrm{T}$ é comumente descrito como um fluxo linear sucessivo entre cada vez mais compartimentos diferenciados. Supondo então que os timócitos em estágios diferentes de maturação estão situados dentro de porções distintas do órgão (SOLAROVIĆ; LALIĆ; LEPOSAVIĆ, 2004).

$\mathrm{O}$ desenvolvimento das células $\mathrm{T}$ intratímicas requer um microambiente estromal íntegro no qual as células epiteliais tímicas constituem a maior parte (BLEUL et al., 2006). O córtex fornece o microambiente necessário para a seleção positiva de timócitos imaturos e a região medular para seleção negativa de células $T$ auto-reativas (BOEHM; BLEUL, 2006). 
Uma hipótese é que a noradrenalina pode influenciar na maturação intratímica da célula $T$, não somente diretamente via $\beta$-adrenoreceptores nas células não-linfóides tímicas, mas também proporcionando assim um microambiente benéfico para a diferenciação e maturação das células T (KURZ, et al.,1997). Dados indicam que a concentração intratímica de noradrenalina aumenta progressivamente do período neonatal até o $60^{\circ}$ pós-natal (LEPOSAVIĆ et al.,1992).

$O$ efeito do tratamento de propranolol na maturação das células $T$ intratímicas em ratos em diferentes estágios de maturação sexual pode ser explicado por dados que demonstram o perfil fenotípico dos timócitos de ratos controle imaturos, o perfil destes é significantemente diferente do perfil dos ratos adultos, a densidade dos $\beta$ adrenoreceptores e a concentração da sua noradrenalina ligante endógena estavam significantemente mais baixas no timo dos ratos imaturos sexualmente do que no timo de ratos adultos (MARCHETTI; MORALE; PALLETIER, 1990; LEPOSAVIĆ et al.,1992).

\subsection{INVOLUÇÃO TíMICA}

Está bem documentado através de trabalhos que o timo possui uma importância significativa no desenvolvimento e manutenção de um sistema imune competente, e que o processo de involução é acelerado após a puberdade quando há uma elevação dos esteróides sexuais no sangue (WINDMILL; LEE, 1998).

Bar-Dayan et al. (1999) também confirma que vários efeitos hormonais e neuroendócrinos (ex. glicocorticóides, hormônio do crescimento, insulina, etc) fazem parte da regulação da involução tímica (BAR-DAYAN et al., 1999).

O timo começa a involuir quando o gato alcança a maturidade sexual e, no gato adulto, é apenas um resquício no mediastino cranial (HUDSON; HAMILTON, 1993).

A duração de vida do timo é curta, com involução variando de meses a anos dependendo da espécie. Como as células T são as células centrais na resposta imune, deve ser temido que a ausência de um timo funcional em um adulto pode causar uma inabilidade de responder a infecções. No entanto, as células T possuem vida longa e se 
auto-replicam, e desta maneira, o timo não é mais requerido no adulto. Ausência total do timo no neonato é um achado clínico incomum e invariavelmente fatal. Existem, contudo, exemplos no qual danos induzidos por vírus ao timo em animais jovens comprometem severamente o sistema imune pela destruição das células $T$ em desenvolvimento. Os dois exemplos detalhados disto tem sido a destruição vista na infecção pela parvovirose canina e leucemia felina induzida por vírus (HALLIWELL; GORMAN, 1989).

Já nas aves o timo persiste por toda a vida do animal, sem involução fisiológica que é observada em outras espécies ou em alguns de seus órgãos como a própria bolsa cloacal (NASCIMENTO, 2002).

Infecções recorrentes em filhotes podem levar a atrofia tímica prematura. Isto ocorre devido à depleção de células $T$ nos órgãos linfóides secundários e no timo. $A$ causa, mais comum de atrofia tímica em gatos é a infecção pelo Vírus da Leucemia Felina (FeLV). Na necropsia, pouco ou nenhum tecido tímico é encontrado nos filhotes. FeLV também causa linfoma tímico, que é comumente observado em gatos de 1 a 2 anos de idade. Nestes casos o timo aumenta de volume, formando uma massa que comprime o pulmão e o coração contra a região dorsocaudal do tórax, ocasionando angústia respiratória para o animal (HUDSON; HAMILTON, 1993).

Em um trabalho realizado em galinhas por Melo e Lage (1987) observaram que os agentes depressores do timo, orgânicos ou não, isto é, produzidos pelo animal ou agindo sobre ele por interferência externa, provocam uma regressão prematura na estrutura histológica do órgão.

Em um estudo realizado por Bar-Dayan et al. (1999), onde compararam a proliferação e apoptose dos timócitos em diferentes partes do timo de camundongos fêmeas, no início e após a rápida fase de declínio da celularidade tímica cortical concluíram que após a involução do timo há uma mudança no balanço entre a proliferação e apoptose especialmente no córtex tímico. Há uma redução no índice de proliferação e uma elevação no índice de apoptose do córtex tímico no camundongo adulto comparado ao camundongo jovem. Esta mudança pode ser considerada pela redução da celularidade do córtex tímico durante a involução tímica. 
Com o avançar da idade do animal, há uma perda progressiva de tecido, o qual é substituído por gordura, contudo, o timo idoso ainda contém ilhas de tecido linfóide, incluindo córtex e medula, e é funcionalmente ativo (TIZARD, 2000).

Em estudos realizados por Windmill, Meade e Lee em 1993 e Windmill e Lee em 1998 observaram que os efeitos da castração em ratos com idade pré-puberdade e adultos tem um efeito benéfico sobre o sistema imune, aumento do crescimento tímico e o processo de involução retardada.

\subsection{TIMECTOMIA}

Até 1961, quando pela primeira vez foi estudado o efeito da timectomia em animais recém-nascidos, as numerosas tentativas de esclarecer as funções do timo haviam falhado. Só então foi observado que a extirpação deste órgão nas primeiras horas após o nascimento resultava numa diminuição sensível no desenvolvimento e no funcionamento do sistema linfóide (CALICH; COPPIVAZ, 1989)

A timectomia feita em camundongos recém-nascidos com um dia de vida faz com que estes animais tornem-se mais susceptíveis às infecções. Um exame mais detalhado destes animais timectomizados no período neonatal revela que há uma diminuição no número de linfócitos circulantes e uma acentuada depressão na capacidade destes animais em certos tipos de resposta imune (TIZARD, 2000). A capacidade de rejeitar enxertos é severamente comprometida, refletindo uma perda total da resposta imune mediada por células e diminuição da resposta imune mediada por anticorpos (TIZARD, 2000; CALICH; COPPIVAZ, 1989).

Os efeitos da timectomia nos mamíferos levam a crer na existência de dois sistemas: um sistema timo-dependente, que seria responsável pelas reações imunológicas de base celular, e outro, representado pelos nódulos linfóides, centros germinativos e plasmócitos, associados com a produção de anticorpos (CALICH; COPPIVAZ, 1989). 
A remoção do timo de animais adultos não produz resultados óbvios imediatos. Se, porém, os animais forem mantidos por vários meses após a operação, observa-se um declínio progressivo no número de linfócitos circulantes e na capacidade destes linfócitos montarem uma resposta imune mediada por células. A interpretação destes resultados sugere que embora o timo no adulto ainda seja funcional, existe um reservatório de células derivadas do timo que deve ser esgotado antes dos efeitos da timectomia tornarem-se aparentes (TIZARD, 2000). 


\section{MATERIAL E MÉTODO}

\subsection{MATERIAL}

Para realização desta pesquisa serão utilizados 12 timos provenientes de fetos de gatos, mortos oriundos de cesariana, subdivididos em 3 grupos etários de 35, 45 e 55 dias de gestação, sendo quatro animais por grupo: dois machos e duas fêmeas, de gatos domésticos oriundos do Hospital Veterinário da Faculdade de Medicina Veterinária e Zootecnia da Universidade de São Paulo - HOVET-FMVZ-USP.

\subsection{MÉTODO}

\subsubsection{Lavagem do sistema circulatório e fixação do timo por meio de perfusão}

A cavidade torácica foi exposta pela incisão nas articulações costo-vertebrais proporcionando a localização dos principais vasos arteriais e venosos do tórax. Foi introduzida, após isolamento da parte torácica da aorta, em sua luz, uma cânula com calibre compatível ao diâmetro do vaso e fixada com fio de sutura, para que em seguida ocorra a secção da veia cava caudal e a veia cava cranial. A perfusão pela aorta foi feita com solução salina tamponada fosfatada (PBS) a $0,1 \mathrm{M}$ e pH 7,4 e heparina a $2 \%$ tendo a função de lavagem dos sistemas arterial e venoso. Para a fixação perfundiu-se pela aorta a solução fixadora de Karnovsky modificada, constituída por glutaraldeído $5 \%\left(\right.$ Merk $\left.^{\circledR}\right)$ e formaldeído a $1 \%\left(\right.$ Sigma $\left.^{\circledR}\right)$ em tampão cacodilato de sódio $\left(\right.$ EMS $\left.^{\circledR}\right)$ a $0,125 \mathrm{M}$ e $\mathrm{pH} 7,4$. 


\subsubsection{Processamento do material}

Os timos foram removidos após a perfusão da solução fixadora de Karnovsky modificada e foram mensurados em seu eixo longitudinal e transversal (em região caudal e cranial). Foram realizados, cortes seccionados transversalmente com a utilização de uma lâmina cortante, produzindo fatias com distância média de $3 \mathrm{~mm}$ e foram imersas no fixador por um período mínimo de 24 horas, sendo posteriormente mensurado a estimativa do volume pelo método de Cavalieri.

O próximo passo foi lavar os fragmentos tímicos em solução cacodilato de sódio $\left(E M S^{\circledR}\right)$ a $0,125 \mathrm{M}$ e pH 7,4 e imersos em uma solução de tetróxido de ósmio $\left(E M S^{\circledR}\right)$ a $2 \%$. As amostras permaneceram nesta solução durante 60 minutos, no escuro e sob agitação constante. Em seguida, foram lavadas na mesma solução tampão de cacodilato anteriormente referida, seguido de água destilada. Foram imersos em solução aquosa de acetato de uranila (Reagen ${ }^{\circledR}$ ) a $3 \%$ durante 60 minutos sob agitação constante e em recipiente escuro.

Os fragmentos foram lavados em água destilada e desidratados em série crescentes de etanóis, sendo em seguida desidratados em óxido de propileno $\left(\mathrm{EMS}^{\circledR}\right)$ por 10 minutos.

Logo após, as amostras foram embebidas em uma solução de óxido de propileno $\left(E M S^{\circledR}\right)$ e resina araldite pura (502 Polyscience Inc. $\left.{ }^{\circledR}\right)$, em constante agitação e em diferentes proporções. Após estas etapas, os fragmentos foram transferidos para resina araldite pura (502 Polyscience Inc. $\left.{ }^{\circledR}\right)$ e levados à estufa $\left(60^{\circ} \mathrm{C}\right)$, permanecendo durante um período mínimo de 48 horas. 


\subsubsection{Microscopia de luz de cortes semi-finos}

Todos os blocos provenientes do material processado foram trimados para evidenciar as regiões de interesse e seccionados seriadamente com $1 \mu \mathrm{m}$ de espessura, com o auxílio do ultra-micrótomo $\mathrm{MT}-\mathrm{XL}^{\circledR}$ equipado com um contador de secções e utilizando navalha de vidro. As secções foram coletadas sobre lâminas e secas em placa térmica (Leica ${ }^{\circledR}$ ) e em seguida coradas com uma solução de azul de toluidina alcoólica. Posteriormente foram cobertas com uma gota de araldite (502 Polyscience Inc. ${ }^{\circledR}$ ) e montadas sob lamínula.

\subsubsection{Volume do órgão ou Volume Referência $\left(\mathrm{V}_{(\mathrm{ref})}\right)$}

Segundo o matemático Bonaventura Cavalieri (1635 apud HOWARD; REED, 1998), o volume de qualquer objeto pode ser estimado através de uma exaustiva série de secções paralelas separadas por uma distância conhecida. A estimativa se dá pela distância entre as secções ( $d$ ou $k$, sendo $d$ a nomenclatura utilizada para cortes macroscópicos e $k$ para cortes microscópicos) multiplicado pela somatória das áreas ( $(\mathrm{a})$ de cada secção (Equação 1)

$$
\text { Equação 1: } \quad V_{(\text {ref })}=\mathrm{d}(\text { ou k }) \times \sum a
$$

Após a retirada dos animais, os timos foram seccionados transversalmente, com o auxílio de uma lâmina cortante, por meio de planos macroscópicos paralelos e seriados, como descrito no trabalho de Henery e Mayhew (1989); Mayhew e Olsen (1991); Mayhew, Mwamengele e Dantzer (1990); Mayhew (1992) e Wulfsohn et al. 
(2004). Cada timo originou em média 4 faixas que constitui uma estimativa eficiente para o cálculo do volume tímico pelo método de Cavalieri (GUNDERSON; JENSEN, 1987; HENERY; MAYHEW, 1989; MAYHEW; OLSEN, 1991; MAYHEW, 1992). A distância entre as fatias $(d)$ não são precisas, então, como proposto por Gunderson et al. (1988b) e Mayhew e Olsen (1991), uma distância média (d) entre as fatias foi estimada através da mensuração do comprimento total do timo, com o auxílio de um paquímetro digital (Starrett ${ }^{\circledR}$ ), A distância média utilizada na maioria dos timos foi de 2,0 $\mathrm{mm}$.

A área das fatias de apenas uma das faces foi calculada, isto é, apenas na face caudal de cada fatia, com o auxílio de um sistema teste, logo, o volume referência dos timos foi obtido através da análise macroscópica.

A acurácia dos resultados obtidos pelo método de Cavalieri foi verificada pelo coeficiente de erro (Equação 2). Este foi calculado pela equação proposta inicialmente por Gundersen e Jensen (1987) e descrita posteriormente em outros trabalhos Pakkenberg et al. (1989); Mayhew e Olsen (1991) e Duerstock et al. (2003).

$$
\text { Equação 2: } \mathbf{C E}=1 / \sum \mathbf{A} \times[1 / 12(3 \mathbf{a}+\mathbf{c}-4 \mathbf{b})]^{1 / 2}
$$

Onde:

$\Sigma \mathbf{A}$ - Somatória de todas as áreas das secções a

a - Somatória dos produtos de a $\mathrm{x}$ a

b - Somatória dos produtos de a $\times(a+1)$

c - Somatória dos produtos de a $\times(a+2)$

\subsubsection{Método Orientator}

O tecido ou órgão isotrópico é aquele onde a estrutura aparece homogeneamente, com as mesmas características em todas as direções, diferente dos 
cortes anisotrópicos onde há uma orientação na apresentação do material (MANDARIM, 1994).

A estimativa de muitos parâmetros estereológicos necessita de secções isotrópicas, ou seja, de cortes AUI (Aleatórios e Uniformemente Isotrópicos) ou IUR (Isotropic Uniform Random) como pré-requisito.Assim, para obtermos cortes AUI ou IUR de qualquer tecido ou órgão utilizamos o método orientator (MATTFELDT et al., 1990).

Este método é utilizado para estimar o comprimento (Lv), densidade de superfície (Sv) e outros parâmetros estereológicos em secções isotrópicas (MATTFELDT et al., 1990). Para este trabalho utilizou-se o método orientator modificado segundo Mattfeldt et al. (1990).

Um fragmento de tecido ou órgão foi seccionado em dois cortes consecutivos. $\mathrm{O}$ primeiro corte foi realizado em um ângulo determinado aleatoriamente, codificado conforme uma tabela de números aleatórios. Depois a face de corte deve ser apoiada no plano da mesa e novamente o tecido foi seccionado segundo um ângulo aleatório. Com isto podemos admitir que os fragmentos obtidos contenham tecido de modo isotrópico, mas o procedimento foi repetido outras vezes para maior segurança (MATTFELDT et al., 1990).

Foi selecionado aleatoriamente uma proporção de fatias cortadas de cada timo. Essas fatias selecionadas permitiram a amostragem do órgão como um todo (WIEBEL, 1979)

Para tornar cada fatia isotrópica, as mesmas foram orientadas de acordo com seu eixo longitudinal e submetidas a sistemas com diferentes ângulos. Cada sistema foi adaptado para o tamanho de cada fatia original e para a amostra formada. Estes sistemas são denominados relógio $\phi$ (seno) ou $\phi$-clock (Figura 2A), e relógio $\theta$ (coseno) ou $\theta$ - clock (Figura 2B). O primeiro sistema utilizado foi o $\phi$-clock, colocou-se a fatia em seu eixo longitudinal no sentido de ângulo $O^{\circ}$, e foi escolhido um ângulo aleatório e a fatia foi seccionada. Um dos dois pedaços formados foi escolhido e colocado no $\theta$ - clock com a face do corte para baixo para ser novamente seccionado em um novo ângulo aleatório. Para a escolha dos valores foi utilizada uma tabela de números aleatórios ("Random Numbers") Os fragmentos foram seccionados até 
atingirem o tamanho ideal (cerca de $1 \mathrm{~mm}^{2}$ ) e foram processados para microscopia de luz de cortes semi-finos.

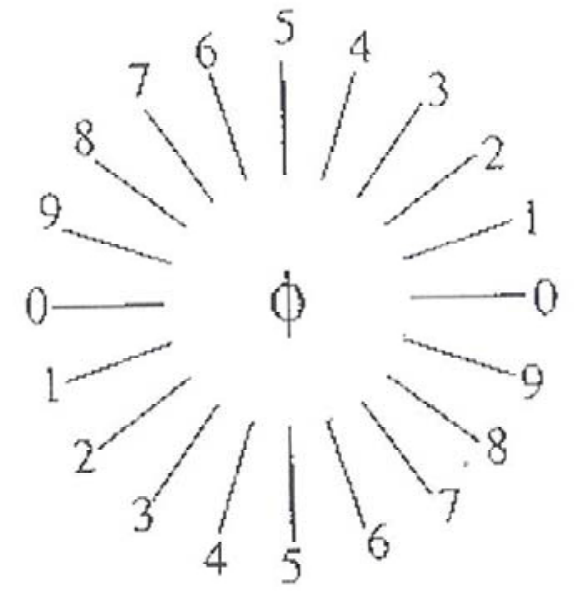

A

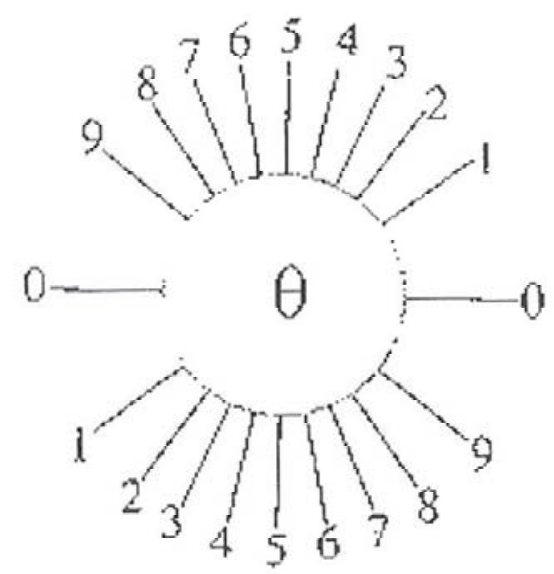

B

Figura 2 - Sistemas testes com diferentes ângulos utilizados no método orientator. A - relógio $\theta$ (co-seno) ou $\theta$ - clock. B - relógio $\phi$ (seno) ou $\phi$-clock

\subsubsection{Análise Estereológica}

O objetivo da estereologia é determinar parâmetros quantitativos tridimensionais de estruturas anatômicas a partir de cortes bidimensionais, valendo-se da geometria e da estatística (MANDARIM, 1994).

Geometricamente os vasos são estruturas tubulares ideais para um eficiente transporte e distribuição de fluídos por todo o organismo. Formam uma rede complexa e ramificada, conectados de forma única, a reconstrução física desta rede é baseada em secções seriadas. O número de capilares na rede equivale com a conectividade, com isso, na prática estereológica o número de capilares é igual à estimação da conectividade (NYENGAARD; BENDTSEN; GUNDERSEN, 1988). 
A área de superfície vascular é o produto do seu comprimento e circunferência, sendo importante para a descrição quantitativa dos vasos (NYENGAARD; BENDSTEN; GUNDERSEN, 1988).

\subsubsection{Método Disector Físico}

A quantificação vascular no timo de gatos foi realizada utilizando o método estereológico do disector físico, descrito inicialmente por Sterio (1984) e por Pakkenberg e Gundersen $(1988,1989)$, associado ao volume referência. O método do disector permite contar partículas independentemente do tamanho, forma, distribuição ou orientação, em um volume conhecido, utilizando pares de secções provenientes de cortes seriados (PAKKENBERG; GUNDERSEN, 1988; COGGESHALL, 1992 COGGESHALL; LEKAN, 1996).

O disector permite a composição das estruturas em três dimensões utilizando um sistema teste com uma área (a) conhecida, número de pontos (p), e um plano paralelo com uma altura (h) (STERIO, 1984).

Cada disector é constituído por duas secções idênticas separadas por uma altura conhecida, sendo estas secções denominadas de "reference-section" e "look-up section", e as partículas encontradas na "reference-section" mas não na "look - up section" são chamadas de "transects" (GAGLIARDO, 2003).

A observação do material e a captura da imagem foram realizadas com o auxílio do microscópio Olympus ${ }^{\circledR}$ BX 60 e de uma câmera digital AxioCam HPC Zeiss ${ }^{\circledR}$, na qual as imagens da "reference section" e da "look -up section" foram capturadas e transferidas para a tela de um computador. Sobre a tela foi aplicado uma área teste (com linhas de inclusão e exclusão) e os perfis vasculares presentes na "referencesection" foram comparados com os perfis da "look-up section". Os perfis identificados em cada secção mudam entre os planos seccionais em três possibilidades para estimar a conectividade.

Os disectores foram aplicados por toda a extensão do timo para permitir que 
todas as regiões apresentassem as mesmas chances de serem amostradas, obedecendo um sistema de amostragem denominado "systematic random sampling scheme" (MAYHEW; GUNDERSEN, 1996).

Foi aplicado por toda a extensão do timo, os disectores, para permitir que todas as regiões apresentassem as mesmas chances de serem amostradas, obedecendo um sistema de amostragem "systematic random sampling scheme" (Mayhew; Gundersen, 1996). Para isso, fez-se necessário estabelecer um intervalo (k) entre as "reference section" ao longo dos disectors utilizados, sendo que a primeira "reference section" analisada foi escolhida aleatoriamente, dentro do intervalo pré-estabelecido, que vai de 1 a k, como preconizado por Gundersen et al. (1988a) e Pakkenberg e Gundersen (1988).

De acordo com Gundersen et al. (1988a) e Mayhew e Gundersen (1996) uma população de 100 a 200 perfis foram contados para estimar a densidade numérica. Assim sendo, é imperativa a necessidade de um estudo piloto para se estabelecer a quantidade de disectors utilizada para atingir este número populacional. Neste trabalho, foi determinado que em torno de 10 disectors nos timos forneciam uma contagem ideal, isto é uma quantidade mínima de 100 perfis.

Sabendo da quantidade de disectors necessária e o tamanho da amostra do timo, este foi mensurado com a utilização de um paquímetro digital (Starret®), foi possível delimitar um intervalo de secções no qual permitiu que todas as regiões dos timos fossem amostradas. Desta forma, foi utilizado um $k=200$ para os timos. A primeira secção de análise do disector, em todos os grupos, foi escolhida de maneira aleatória como descrita anteriormente.

A área teste (At) utilizada foi definida por um conjunto de linhas (retas) e pontos, além de linhas de inclusão e exclusão (Figura 3), onde os perfis que tocam as linhas de exclusão não são considerados, permitindo uma igual chance de amostragem dos perfis, independente do tamanho destes, em uma abordagem imparcial. Este foi sobreposto à imagem morfológica para a contagem estereológica. 
A

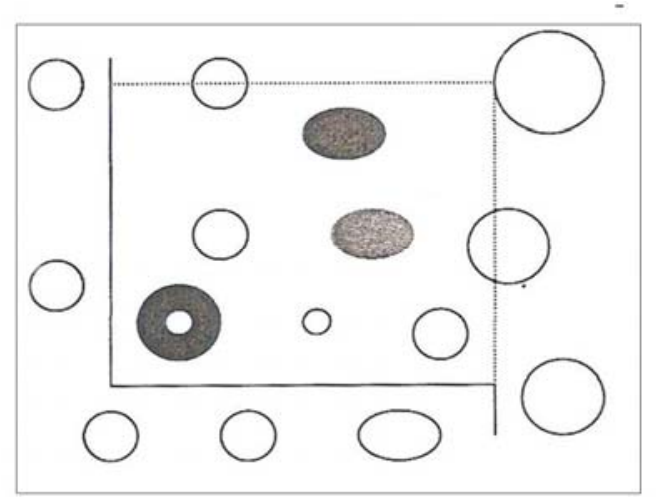

B

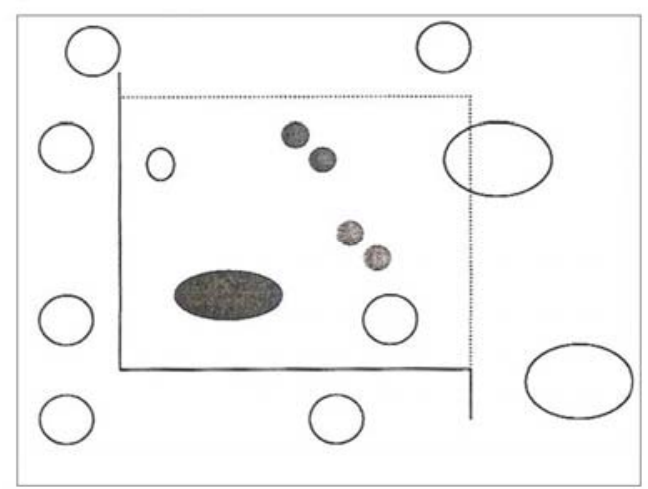

Figura 3 - Em A, a "reference section" é delimitada por uma área teste com linhas de inclusão (linhas pontilhadas) e de exclusão (linhas cheias). Em B, a "look-up section" é delimitada por uma área teste rígida

No disector com área $=\mathrm{a}$, e com a distância entre as secções $=\mathrm{h}$, o volume do disector $\left(\mathrm{v}_{(\mathrm{dis})}\right)$ é calculado de acordo com equação 3.

$$
\text { Equação } 3: \mathbf{v}_{\text {(dis) }}=\mathrm{a} \cdot \mathrm{h}
$$

\subsubsection{Determinação do Número de Euler no Método de Disector}

O princípio de ConnEulor ou de conectividade é uma extensão do método de disector para a estimação do número de estruturas. Cada estrutura tem um número de Euler ou conectividade que é obtido com exaustivas secções seriadas da amostra (DEHOFF et al., 1972; KROUSTRUP; GUNDERSEN, 2001).

O número de Euler é um valor inteiro, específico, que pode ser definido por algumas estruturas em alguma dimensão (DEHOFF et al., 1972; KROUSTRUP; GUNDERSEN, 2001). Sua estimação é independente da direção e orientação da leitura. 
O conceito de conectividade está intimamente relacionado com a integridade geométrica das curvas de superfície, esta estimação estreológica foi estudada primeiramente por F. Rhine's e R. Dehoff's na Flórida (NYENGAARD; BENDTSEN; GUNDERSEN, 1988).

De acordo com Kroustrup e Gundersen (2001) e Nyengaard, Bendtsen e Gundersen (1988) para estimar a conectividade deve-se enumerar os chamados planos tangenciais. Em cada ponto de uma superfície lisa no espaço tridimensional pode-se definir a curvatura da superfície, que é de três tipos:

- Superfície do lúmen do capilar convexa, sendo caracterizado por uma saliência externa, o raio da curvatura tem seus eixos na margem luminal da superfície, conferindo partes completamente fechadas chamadas de "Hole", $\mathrm{H}$ ou fragmentos luminais (Figura 4A).

- Superfície côncava, sendo o oposto da convexa, conferindo uma nova parte isolada chamada de "Island", I, da parede interna do lúmen, aparentando um lago luminal (luminal lagoon) (Figura 4B).

- Superfície em sela ou "Saddle surface" é complexa: em uma direção (desigual ao longo de todo o eixo capilar) a curvatura é côncava com o centro do raio da curvatura saindo do lúmen, na outra direção (do outro lado do capilar) a curvatura é, normalmente, do tipo convexa, é a divisão do lúmen capilar em dois ou mais lumens, uma conexão luminal ou uma nova conexão entre as partes isoladas chamadas também de "Bridge", B (Figura 4C). 
Estrưtura

A

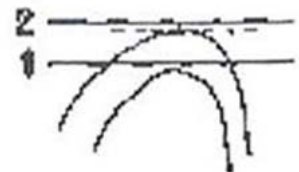

$B$
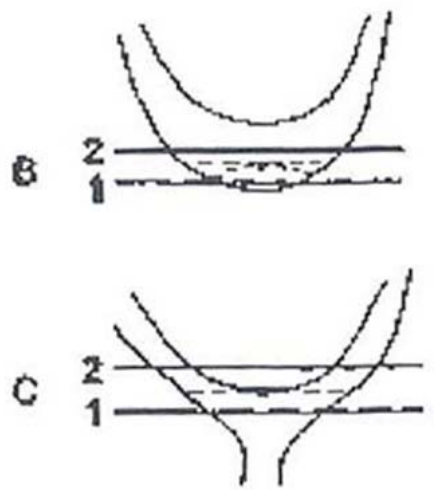

1: Reference
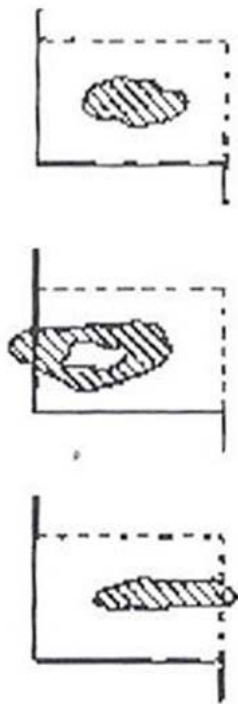

2: Look-up

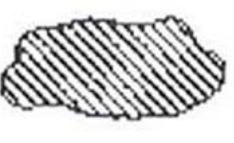

$\omega$

Figura 4 - Amostragem do disector e estimação dos planos tangenciais. Em A, a superfície convexa do capilar é mostrado na "reference setion" e não na "Lookup section", estruturas chamadas de "Hole". Em B, uma irregularidade da parede do capilar é observada conferindo uma nova parte isolada chamada de "Island". Em C, na "reference section" a curvatura é côncava, e na "look-up section" a curvatura é do tipo convexa formando uma divisão do lúmen capilar em dois ou mais lumens, chamados também de "Bridge"

Assim, segundo Kroustrup e Gundersen (2001), as "Bridges" contribuem com -1, e as "Islands" e "Holes" contribuem com +1, formando a equação 4.

$$
\begin{aligned}
& \text { Equação 4: } \quad \Sigma \mathrm{X}=\Sigma \mathrm{I}-\Sigma \mathrm{B}+\sum \mathrm{H} \\
& 2
\end{aligned}
$$

Onde:

$\Sigma \mathrm{X}=$ número total de Euler 


$$
\begin{aligned}
& \sum \mathrm{I}=\text { número total de "Islands" } \\
& \sum \mathrm{B}=\text { número total de "Bridges" } \\
& \sum \mathrm{H}=\text { número total de "Holes" }
\end{aligned}
$$

A constante 2 no denominador, reflete que a contagem de "Islands", "Bridges", "Holes" no disector é representado nas duas direções simultaneamente.

Em uma amostra uniforme e randômica do disector a densidade do número de Euler $\left(X_{v}\right)$ é estimada de acordo com a equação 5 .

$$
\text { Equação 5: } X_{v}=\frac{\sum X}{\sum_{v \text { (dis) }}}
$$

3.2.6.3 Estimação da Densidade Numérica Vascular $\left(\mathrm{N}_{\mathrm{v}(\operatorname{vasc})}\right)$

Calculando a área do sistema teste (a) e o número de Euler na "reference section" com a respectiva "look-up section", obtemos a densidade numérica vascular $\left(\mathrm{N}_{\mathrm{v}(\mathrm{vasc})}\right)$, ou densidade de conectividade (NYENGAARD; MARCUSSEN, 1993)

$$
\text { Equação 6: } \quad \mathrm{N}_{\mathrm{v}(\text { vasc })}=\frac{-\sum \mathrm{X}}{2 \cdot \mathrm{h} \cdot \sum \mathrm{a}}
$$

Onde:

$\Sigma X=$ Número de Euler

$\mathrm{H}=$ Altura do disector, distância entre os 2 planos de secções

$\sum \mathrm{a}=$ Total de áreas dos disectores 
3.2.6.4 Número Total de Vasos no Órgão $\left(\mathrm{N}_{(\text {vasc })}\right)$

Com a densidade numérica e o volume referência do órgão calculado pelo método de Cavalieri, obtemos o número total de vasos no órgão de acordo com Kroustrup e Gundersen (2001) (Equação 7).

Equação $7: \quad \mathbf{N}_{\text {(vasc) }}=\mathbf{N}_{\mathrm{v}(\text { vasc })} \cdot \mathbf{N}_{\text {(ref) }}$

3.2.6.5 Estimação da densidade de comprimento do vaso (Lv), comprimento do vaso (L), densidade de superfície de área (Sv), superfície de área (S)

A estimação do comprimento requer planos isotrópicos, sendo a estrutura maior que o diâmetro (MATTFELDT et al., 1990).

Segundo Nyengaard (1993), a densidade de comprimento do vaso (Lv) e a densidade de superfície de área (Sv) são estimadas de acordo com as equações 8 e 9.

Equação 8: Lv = 2. Qa

Onde :

Qa $=$ Perfis de vaso por área

Equação 9: $S v=2 . I_{L}$

Onde:

$\mathrm{I}_{\mathrm{L}}=$ Número de intersecções entre os vasos e as linhas do sistema teste.

Para obtermos o comprimento do vaso e a área de superfície, multiplica-se a densidade de comprimento (Lv) e a densidade de superfície (Sv) pelo volume de referência do órgão $\left(V_{(r e f)}\right)$, equações 10 e 11.

Equação 10: $L=L v \cdot V_{(\text {ref })} \quad$ Equação 11: $S=S v \cdot V_{(\text {ref })}$ 


\section{RESULTADOS}

Os resultados obtidos dos três grupos etários foram subdivididos quanto aos aspectos relativos à anatomia macroscópica, anatomia microscópica e análise estereológica.

\subsection{ANATOMIA MACROSCÓPICA DO TIMO}

O timo dos gatos dos diferentes grupos etários analisados apresentavam coloração rosa pálido, localizados no mediastino cranial, entre os pulmões e dorsalmente à base do coração. Algumas particularidades foram encontradas em alguns fetos irmãos onde ocorreu variação da forma do órgão entre animais da mesma ninhada, e entre faixa etária diferentes, quanto à morfologia e número de lobos tímicos.

No grupo I (35 dias) um feto macho apresentou macroscopicamente os lobos torácicos divididos em direito e esquerdo em região de tórax e no final da porção cervical. Dois fetos machos apresentaram macroscopicamente uma única massa sem divisão com vestígio do lobo direito em região torácica. E um feto fêmea apresentou macroscopicamente os lobos torácicos totalmente divididos em direito e esquerdo unidos por um fino tecido conjuntivo. Neste caso, o lobo torácico direito está dividido em porção cranial e caudal enquanto que o esquerdo não apresentava divisão aparecendo como uma massa única. O lobo intermediário se apresentou emitindo tecido para divisão em região cervical direita e esquerda.

Duas fêmeas deste mesmo grupo apresentaram macroscopicamente uma massa única em região torácica totalmente dividida em lobo direito e esquerdo, indicando ser lobo torácico, sem vestígios ainda de lobo cervical.

No grupo III (55 dias) um feto fêmea apresentou macroscopicamente extensão do lobo torácico direito além do primeiro par de costelas em região cervical para o lado direito. Neste mesmo grupo dois fetos fêmeas apresentaram macroscopicamente uma 
extensão que ultrapassava o $1^{\circ}$ par de costelas, se ramificava delgadamente pelo lado esquerdo entre o esôfago e a traquéia cervical.

\subsubsection{Esqueletopia}

Após a ressecção do membro torácico esquerdo e musculatura torácica, foram removidas a $2^{\circ}, 3^{\circ}$ e $4^{\circ}$ costelas do antímero esquerdo evidenciando o lobo tímico esquerdo que está localizado em região de $1^{\circ}$ a $5^{\circ}$ costela torácica, ventralmente e medialmente ao lobo cranial do pulmão esquerdo (Figura 5).

A porção tímica torácica direita relacionou-se caudalmente com o coração e medial e ventralmente ao lobo cranial pulmonar direito (Figura 6).

A porção esquerda do lobo torácico relacionou-se caudalmente com a aurícula direita do coração, dorsalmente relaciona-se com o esôfago torácico, lateralmente em região de incisura tímica entre os lobos cervicais e torácicos observa-se adentrando a incisura a A. torácica interna esquerda. Esta porção esquerda do lobo torácico relacionou-se ventralmente e medialmente com o lobo cranial do pulmão esquerdo. $O$ lobo esquerdo tímico é maior quando relacionado ao lobo direito.

Observam os sulcos em região de transição dos lobos torácicos para os lobos cervicais dividindo estes lobos, e nestes sulcos foi observada a confluência da artéria e veia torácica interna.

A porção cervical do timo relacionou-se com o terço distal da traquéia cervical e esta porção está localizava-se ventralmente a traquéia, aparecendo com a forma fina e estreita (Figura 7). 


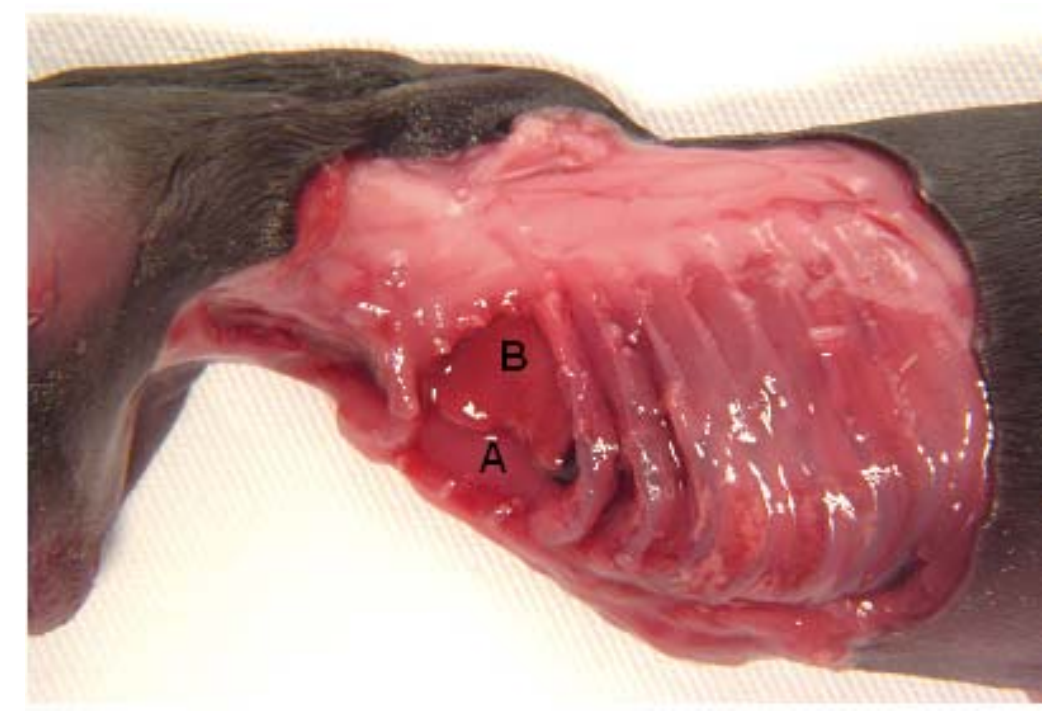

Figura 5 - Fotografia de região torácica de feto de gato com remoção da $2^{\mathrm{a}}$ até $4^{\mathrm{a}}$ costela torácica, evidenciando lobo tímico esquerdo $(A)$ e lobo cranial pulmonar esquerdo (B)

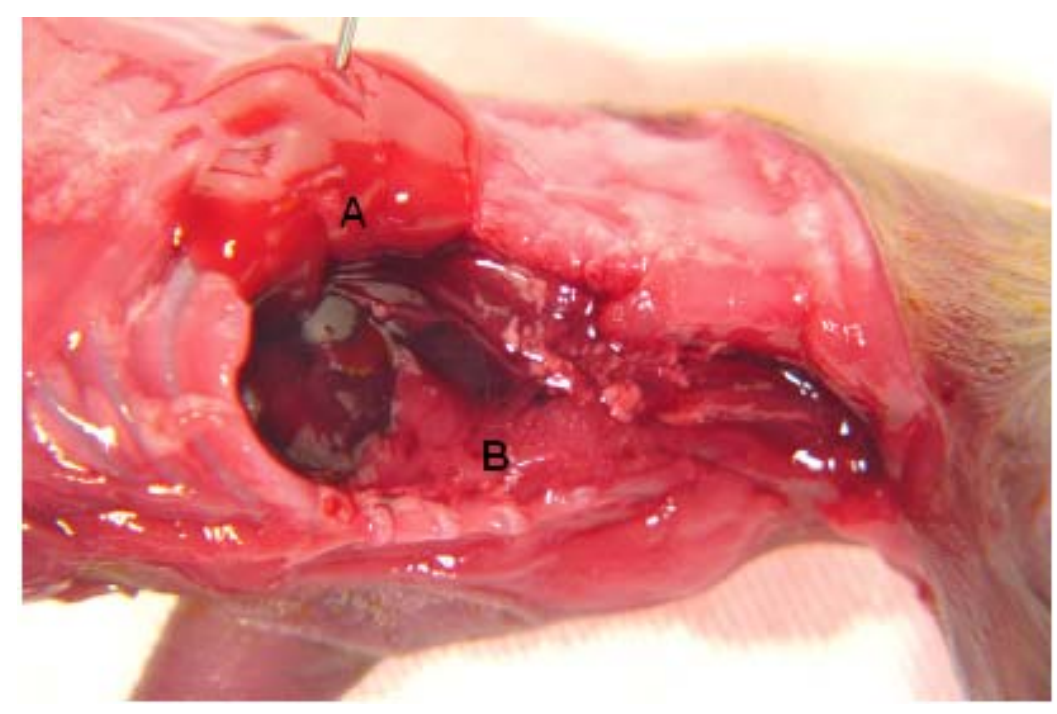

Figura 6 - Fotografia de região torácica de feto de gato com remoção das costelas e deslocamento do pulmão direito $(A)$ para evidenciar o timo direito $(B)$ 


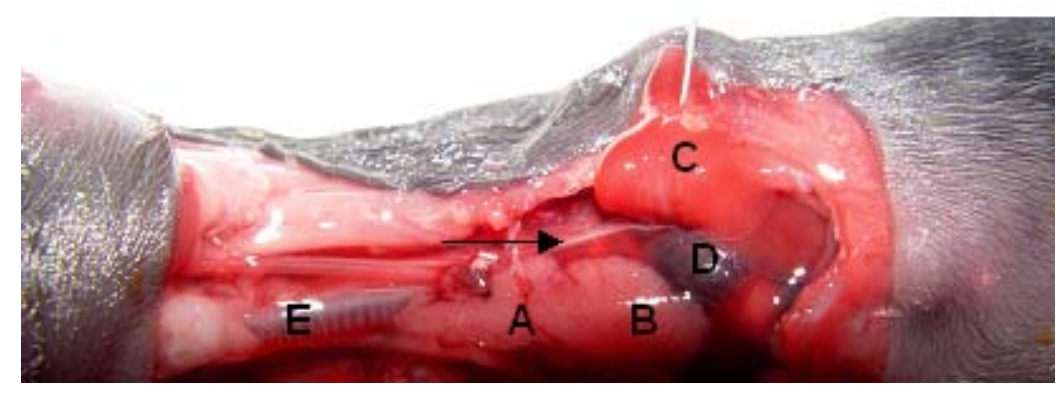

Figura 7 - Fotografia de timo de feto de gato de 55 dias A: lobo tímico cervical esquerdo. B: lobo tímico torácico esquerdo. C: lobo pulmonar cranial esquerdo. D: coração. Seta preta: nervo vago. E: traquéia

De forma geral, o comprimento, a espessura e a largura do timo apresentaram um aumento gradativo conforme o aumento da faixa etária e desenvolvimento dos fetos.

No grupo I o comprimento médio foi de $1,2 \mathrm{~cm}$, sendo que nas fêmeas $1,05 \mathrm{~cm}$ e nos machos 1,35. A espessura média foi de $0,25 \mathrm{~cm}$, sendo nas fêmeas $0,25 \mathrm{~cm}$ e nos machos $0,25 \mathrm{~cm}$. A largura média foi de $0,25 \mathrm{~cm}$, sendo nas fêmeas $0,25 \mathrm{~cm}$ e nos machos $0,25 \mathrm{~cm}$. Neste grupo o comprimento teve diferença estatisticamente significante quando comparado ao sexo.

No grupo II o comprimento médio foi de $2,4 \mathrm{~cm}$, sendo em média nas fêmeas 2,7 $\mathrm{cm}$, e nos machos $2,1 \mathrm{~cm}$. A espessura média foi de $0,28 \mathrm{~cm}$ sendo nas fêmeas e 0,32 $\mathrm{cm}$ nos machos $0,25 \mathrm{~cm}$. A largura média foi de $0,375 \mathrm{~cm}$, sendo nas fêmeas $0,35 \mathrm{~cm}$ e nos machos $0,4 \mathrm{~cm}$. Neste grupo somente a espessura teve diferença estatisticamente significante quando comparado ao sexo.

No grupo III o comprimento médio foi de $3,05 \mathrm{~cm}$, sendo nas fêmeas $3,3 \mathrm{~cm}$ e nos machos $2,8 \mathrm{~cm}$. A espessura média foi de $0,3625 \mathrm{~cm}$, sendo nas fêmeas $0,35 \mathrm{~cm}$ e nos machos $0,375 \mathrm{~cm}$. A largura média foi de $0,63 \mathrm{~cm}$, sendo nas fêmeas $0,72 \mathrm{~cm}$ e nos machos $0,55 \mathrm{~cm}$. Neste grupo somente a largura teve diferença estatisticamente 
significante quando comparada ao sexo.

O volume do órgão ou volume referência (Vref) - $\mathrm{cm}^{3}$ - estimado pelo método de Cavalieri apresentou valores que aumentavam gradativamente de acordo com o desenvolvimento dos fetos, sendo maior nas fêmeas dos grupos I e III quando analisada a mesma faixa etária. O média do volume referência no grupo I foi de 0,077, sendo nos machos 0,075 e nas fêmeas 0,08 . No grupo II média foi de 0,215 , sendo nos machos 0,235 e nas fêmeas 0,195 . No grupo III a média foi de 0,252 , sendo nos machos 0,245 e nas fêmeas 0,26 . Houve diferença estatisticamente significante se comparado o sexo no grupo II, e quando comparado às faixas etárias entre os grupos I e II, I e III.

Os valores individuais tais como volume referência, comprimento, espessura e largura do timo estão apresentados sistematicamente nas tabelas 1 e 2. 
Tabela 1 - Valores das variáveis, volume referência $\left(V_{(\text {ref })}\right)$, comprimento, espessura largura do timo em fetos machos nos diferentes grupos etários. São Paulo - 2007

Grupos $\quad \mathbf{V}_{(\mathrm{ref})}\left(\mathrm{cm}^{3}\right) \quad$ Comprimento (cm) $\quad$ Espessura (cm) Largura (cm)

(Machos)

I (35 dias)

$\begin{array}{lllll}1 & 0,1 & 1,4 & 0,3 & 0,2\end{array}$

$\begin{array}{lllll}2 & 0,05 & 1,3 & 0,2 & 0,3\end{array}$

\begin{tabular}{lllll}
\hline Média & 0,075 & 1,35 & 0,25 & 0,25 \\
DP & 0,035355 & 0,070711 & 0,070711 & 0,070711 \\
\hline
\end{tabular}

II (45 dias)

$\begin{array}{lllll}1 & 0,14 & 1,9 & 0,2 & 0,3\end{array}$

$\begin{array}{lllll}2 & 0,33 & 2,3 & 0,3 & 0,5\end{array}$

\begin{tabular}{lllll}
\hline Média & 0,235 & 2,1 & 0,25 & 0,4 \\
DP & 0,13435 & 0,282843 & 0,070711 & 0,141421 \\
\hline III (55 dias) & & & & \\
1 & 0,25 & 2,6 & 0,35 & 0,6 \\
& & & & \\
2 & 0,24 & 3,0 & 0,4 & 0,5 \\
& & & & \\
\hline Média & 0,245 & 2,8 & 0,375 & 0,55 \\
DP & 0,007071 & 0,282843 & 0,035355 & 0,070711 \\
\hline
\end{tabular}


Tabela 2 - Valores das variáveis, volume referência $\left(\mathrm{V}_{(\mathrm{ref})}\right)$, comprimento, espessura largura do timo em fetos fêmeas nos diferentes grupos etários. São Paulo - 2007

\begin{tabular}{|c|c|c|c|c|}
\hline $\begin{array}{l}\text { Grupos } \\
\text { (Fêmeas) }\end{array}$ & $V_{(\mathrm{ref})}\left(\mathrm{cm}^{3}\right)$ & Comprimento (cm) & Espessura (cm) & Largura $(\mathrm{cm})$ \\
\hline \multicolumn{5}{|l|}{ I (35 dias) } \\
\hline 3 & 0,1 & 1,1 & 0,3 & 0,3 \\
\hline 4 & 0,06 & 1,0 & 0,2 & 0,2 \\
\hline Média & 0,08 & 1,05 & 0,25 & 0,25 \\
\hline DP & 0,028284 & 0,070711 & 0,070711 & 0,070711 \\
\hline \multicolumn{5}{|l|}{ II (45 dias) } \\
\hline 3 & 0,15 & 1,7 & 0,25 & 0,4 \\
\hline 4 & 0,24 & 3,7 & 0,4 & 0,3 \\
\hline Média & 0,195 & 2,7 & 0,325 & 0,35 \\
\hline DP & 0,06364 & 1,414214 & 0,106066 & 0,070711 \\
\hline \multicolumn{5}{|l|}{ III (55 dias) } \\
\hline 3 & 0,24 & 2,7 & 0,3 & 0,47 \\
\hline 4 & 0,28 & 3,9 & 0,4 & 0,49 \\
\hline Média & 0,26 & 3,3 & 0,35 & 0,48 \\
\hline DP & 0,028284 & 0,848528 & 0,070711 & 0,014142 \\
\hline
\end{tabular}

As diferenças das variáveis comparando a faixa etária e os sexos estão representados na figura 8 . 
A

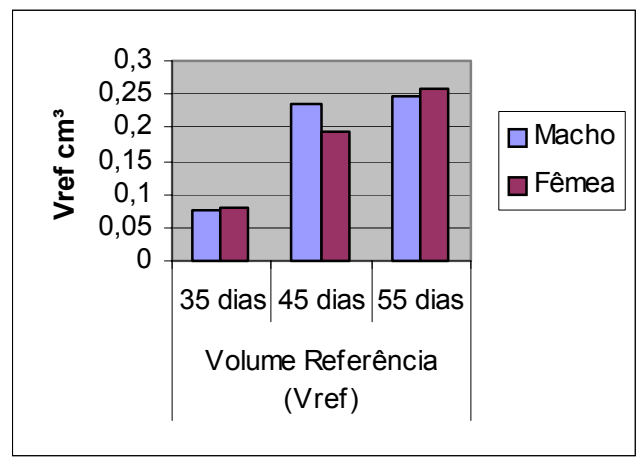

C

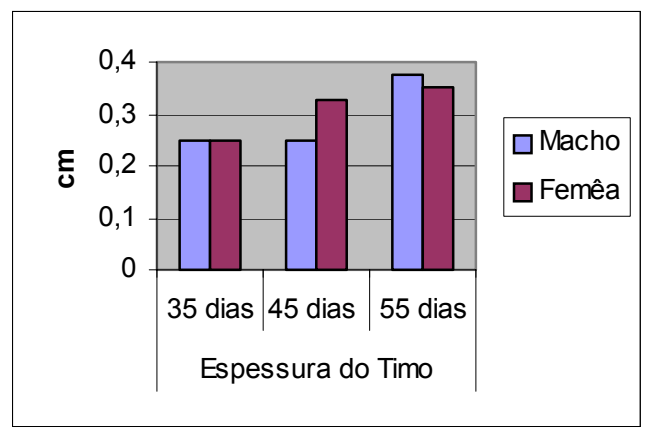

B

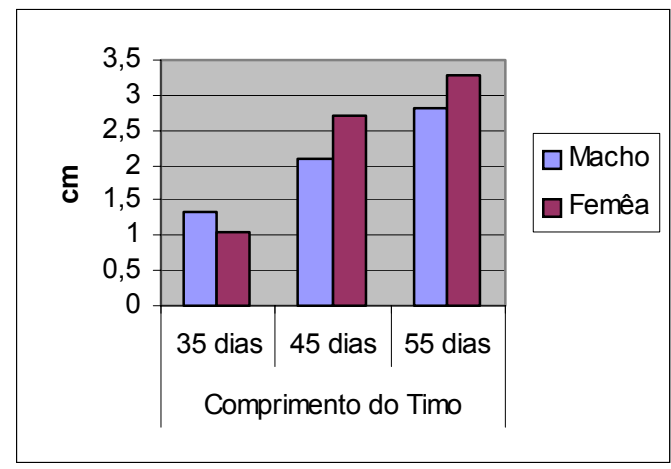

D

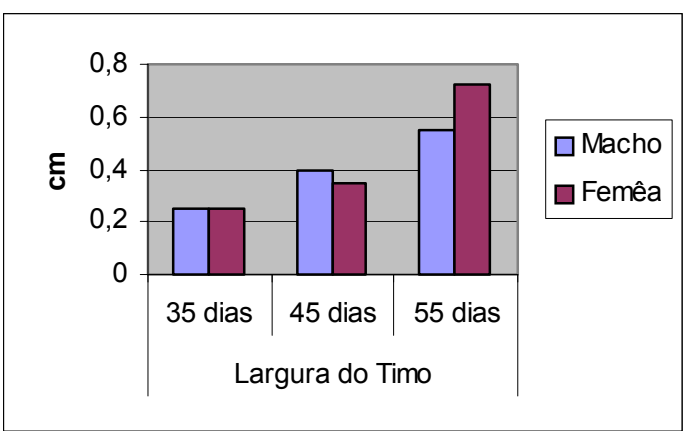

Figura 8 - Histograma comparando as variáveis, volume referência, comprimento, espessura e largura do timo entre as faixas etárias e o sexo. A: Volume referência $\left(\mathrm{V}_{(\text {ref })}\right)$. B: comprimento do timo. C: espessura do timo. D: largura do timo - São Paulo 2007 


\subsection{ANATOMIA MICROSCÓPICA DO TIMO}

O timo é revestido por uma cápsula de tecido conjuntivo que emite invaginações formando septos que dividem parcialmente o lobo formando a estrutura lobular. Os vasos sangüíneos adentram os lobos juntamente com os septos, se ramificando no percurso dos septos interlobulares e alcançando o parênquima tímico.

Com o método orientator, o órgão passou a ser isotrópico, assim não há como diferenciar a região cortical e medular nos cortes semi-finos.

O parênquima do órgão se apresentou bem heterogêneo em algumas regiões devido às células em diferentes estágios de maturação, e em outras regiões de forma homogênea.

Os corpúsculos de Hassal foram evidenciados em todos os grupos, mas no grupo III houve um aparecimento mais freqüente destas estruturas.

Nos animais do grupo I e II, o timo apresentou-se de forma heterogênea com uma população de células se reorganizando, quando comparados com o grupo III que se apresenta de forma mais organizada e homogênea. Não foram notadas diferenças visuais entre machos e fêmeas.

Os arranjos celulares do grupo I, II e III são semelhantes, sendo caracterizados pelas células mais agrupadas, e com os vasos aumentando de calibre conforme o crescimento do animal. 


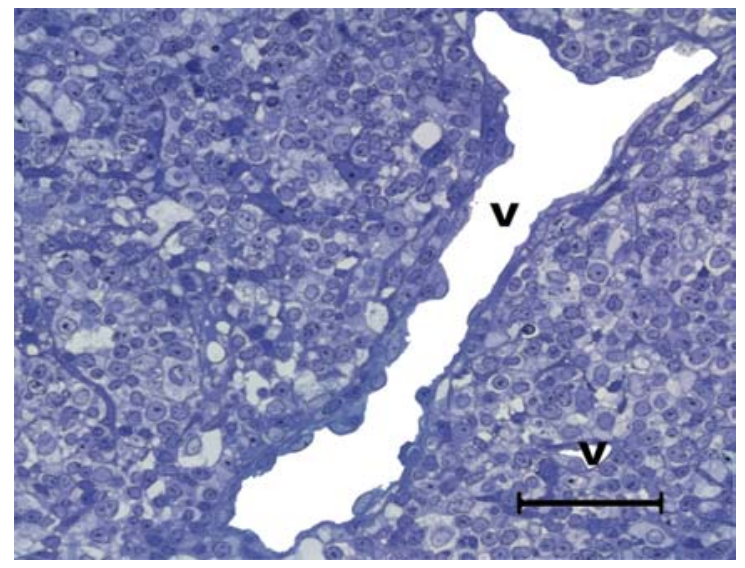

A

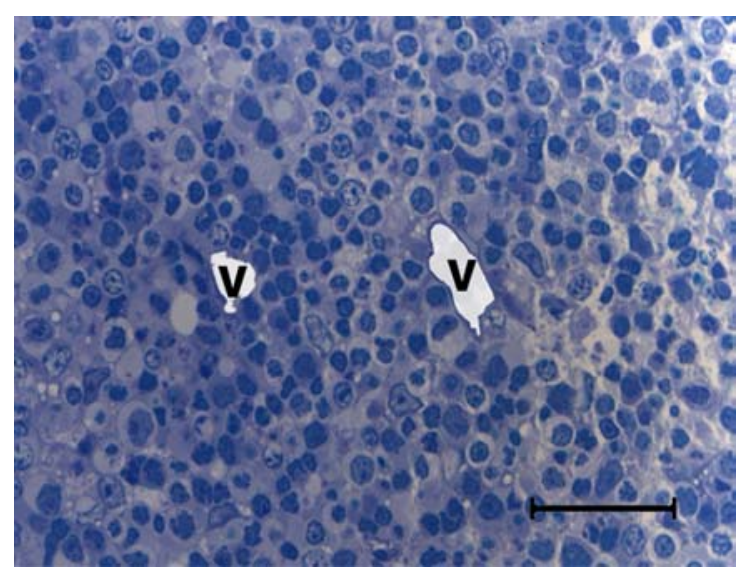

C

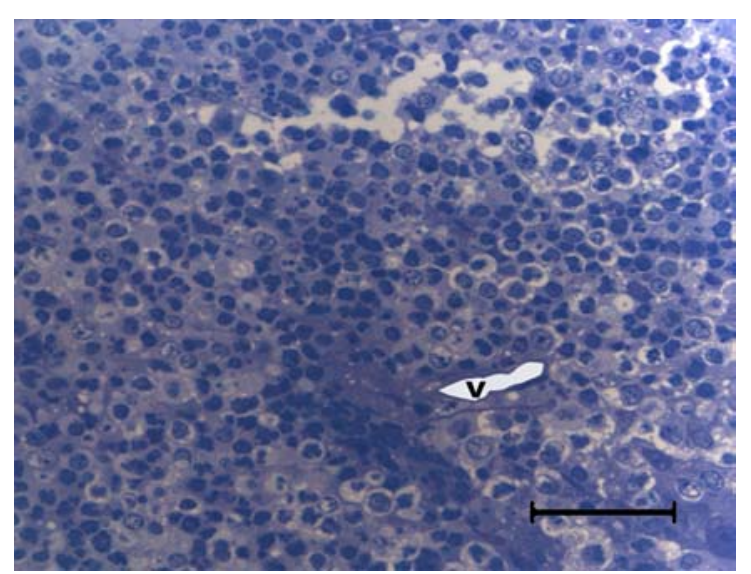

\section{E}

Figura 9 - Fotomicrografias dos timos. A e B: feto com 55 dias, fêmea (Barra

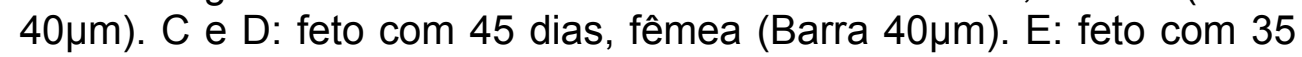

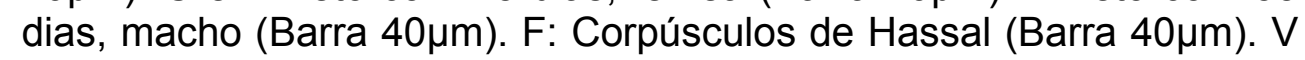
- Vaso

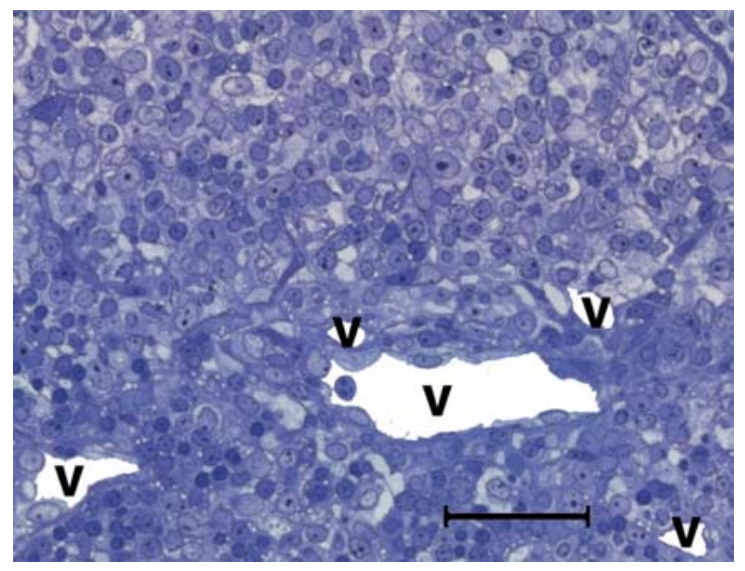

B

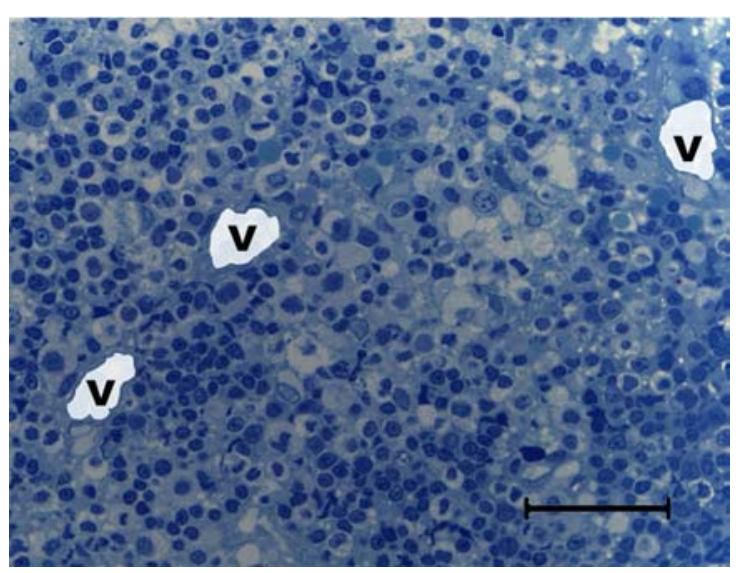

D

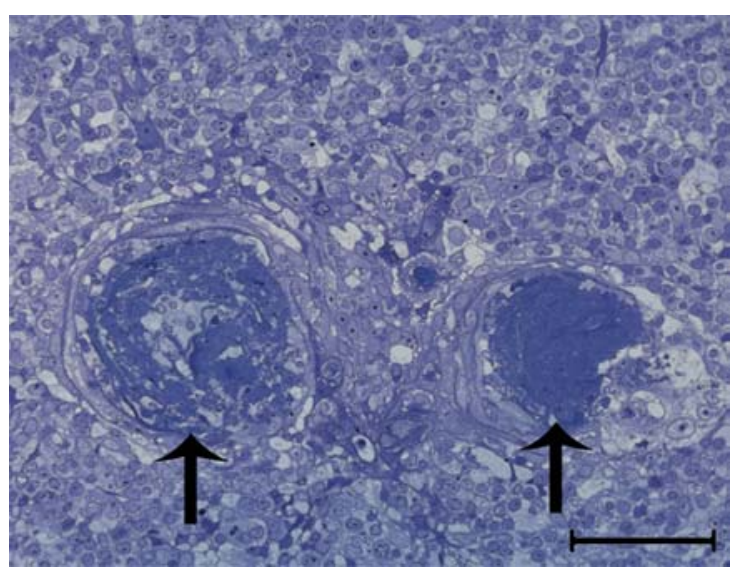

$\mathbf{F}$ 


\subsection{ANÁLISE ESTEREOLÓGICA}

A estimação da densidade de comprimento do vaso (Lv) teve um aumento gradativo no grupo I e II das fêmeas e no III uma elevação significante. No grupo II dos machos houve uma queda em relação ao I e no grupo III houve um aumento significativo. A média de densidade de comprimento do vaso no grupo I foi de 295 , sendo nos machos de 306 e nas fêmeas de 284; no grupo II de 175,5, sendo nos machos de 120 e nas fêmeas de 231; no grupo III de 387,5, sendo nos machos de 409 e nas fêmeas de 366 .

O comprimento do vaso (L), em mm, apresentou média de 26,22 no grupo I, sendo nos machos de 21,84 e nas fêmeas de 30,6; no grupo II a média foi de 35,3, sendo nos machos 23,26 e nas fêmeas 47,34; no grupo III foi de 97,31 , sendo nos machos 100,3 e nas fêmeas 94,32 .

A média da densidade de superfície de área (Sv) no grupo I foi de 240,5, sendo nos machos 240 e nas fêmeas 241; no grupo II foi de 132, sendo nos machos de 88 e nas fêmeas de 176; no grupo III foi de 295, sendo nos machos de 386 e nas fêmeas 204.

A média da superfície de área (S), em $\mathrm{mm}^{2}$, no grupo I foi de 21,05 , sendo nos machos 24 e nas fêmeas 18,1; no grupo II foi de 30,56, sendo nos machos 25 e nas fêmeas 36,12; no grupo III foi de 90,635 , sendo nos machos 128,39 e nas fêmeas 52,88 . 
A média da densidade numérica vascular $\left(\mathbf{N}_{\mathrm{v}(\mathrm{vasc})}\right)$, em $\mathrm{cm}^{3}$, no grupo I foi de 84 , sendo nas fêmeas 95 e nos machos 73. No grupo II a média foi de 49 , sendo que nas fêmeas foi de 72 e nos machos foi de 26 . No grupo III a média foi de 38 , sendo que nas fêmeas foi de 54 e nos machos foi de 22.

A média do número total de vasos no órgão $\left(\mathbf{N}_{\text {(vasc) }}\right)$ no grupo I a média foi de 404, sendo nas fêmeas 70 e nos machos 738. No grupo II a média foi de 488, sendo que nas fêmeas foi de 60 e nos machos 916. No grupo III a média foi de 206, sendo que nas fêmeas foi de 144 e nos machos foi de 268. Os valores apresentaram-se maiores nos machos do que nos fêmeas.

Os resultados apresentados tais como: estimação da densidade de comprimento do vaso (Lv), comprimento do vaso (L), densidade de superfície de área (Sv), superfície de área $(\mathrm{S})$, estimação da densidade numérica vascular $\left(\mathrm{N}_{\mathrm{v}(\mathrm{vasc})}\right)$, número total de vasos no órgão $\left(\mathrm{N}_{(\text {vasc) }}\right)$ estão apresentados sistematicamente nas tabelas 3 e 4.

As diferenças das variáveis comparando a faixa etária e os sexos estão representados na figura 9 . 
Tabela 3 - Valores das variáveis densidade de comprimento do vaso (Lv), comprimento do vaso (L), densidade de superfície de área (Sv), superfície de área (S), estimação da densidade numérica vascular $\left(\mathrm{N}_{\mathrm{v}(\mathrm{vasc})}\right)$, número total de vasos no órgão $\left(\mathrm{N}_{(\mathrm{vasc})}\right)$, do timo em fetos fêmeas nos diferentes grupos etários - São Paulo - 2007

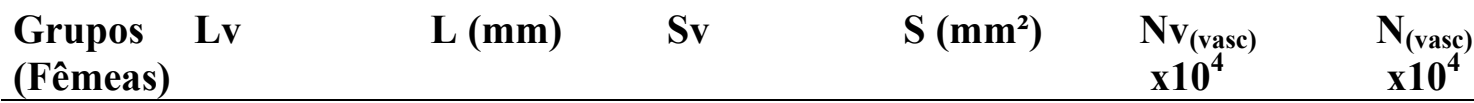

I $\quad(35$

dias)

\begin{tabular}{lllllll}
3 & 240 & 24 & 182 & 18,2 & 6640625 & 6640625 \\
4 & 328 & 19,68 & 300 & 18 & 1250000 & 7500000 \\
\hline Média & 284 & 21,84 & 241 & 18,1 & 95,7 & 70,7031 \\
DP & 62,22539 & 3,054701 & 83,43860 & 0,141421 & 4143 & 6076
\end{tabular}

$\begin{array}{lllllll}\text { DP } & 62,22539 & 3,054701 & 83,43860 & 0,141421 & 4143 & 6076\end{array}$

II $\quad(45$

dias)

$3 \quad 180$

\begin{tabular}{lllll}
4 & 282 & 67,68 & 216 & 51, \\
\hline Média & 231 & 47,34 & 176 & 36,
\end{tabular}

72,12489

$28,52468 \quad 56,56854$

20,4

1029411

1544117

51,84

427083 10625000

III $\quad(55$

dias)

\begin{tabular}{lllllll}
3 & 408 & 97,92 & 212 & 50,88 & 4310344 & 1034482 \\
4 & 324 & 90,72 & 196 & 54,88 & 6640625 & 1859375 \\
\hline Média & 366 & 94,32 & 204 & 52,88 & 54,7 & 144,6929 \\
DP & 59,39696 & 5,091168 & 11,31370 & 2,828427 & 1647 & 5832 \\
\hline
\end{tabular}


Tabela 4 - Valores das variáveis densidade de comprimento do vaso (Lv), comprimento do vaso (L), densidade de superfície de área (Sv), superfície de área (S), estimação da densidade numérica vascular $\left(\mathrm{N}_{\mathrm{v}(\mathrm{vasc})}\right)$, número total de vasos no órgão $\left(\mathrm{N}_{(\mathrm{vasc})}\right)$, do timo em fetos machos nos diferentes grupos etários - São Paulo - 2007

\begin{tabular}{|c|c|c|c|c|c|c|}
\hline $\begin{array}{l}\text { Grupos } \\
\text { (Machos) }\end{array}$ & $\mathbf{L v}$ & $\mathbf{L}(\mathbf{m m})$ & Sv & $\mathrm{S}\left(\mathrm{mm}^{2}\right)$ & $\begin{array}{l}N_{\text {(vasc) }} \\
x_{10}^{4}\end{array}$ & $\begin{array}{l}\mathbf{N}_{\text {(vasc) }} \\
\mathbf{x 1 0}\end{array}$ \\
\hline $\begin{array}{l}\text { I } \\
\text { dias })\end{array}$ & & & & & & \\
\hline 1 & 290 & 29 & 162 & 16,2 & 146226 & 1462261 \\
\hline 2 & 322 & 32,2 & 318 & 31,8 & 1329787 & 13297872 \\
\hline Média & 306 & 30,6 & 240 & 24 & 73,8 & 738,0067 \\
\hline DP & 22,627417 & 2,26274 & 110,30865 & 11,030865 & 836 & 836 \\
\hline
\end{tabular}

II $\quad(45$

dias)

\begin{tabular}{lllllll}
1 & 172 & 24,08 & 46 & 6,44 & 572916 & 8020824 \\
2 & 68 & 22,44 & 132 & 43,56 & 4656862 & 15367644 \\
\hline Média & 120 & 23,26 & 88 & 25 & 26,14 & 916,9423 \\
DP & 73,539105 & 1,1596551 & 60,811183 & 26,247803 & 288 & 519 \\
\hline
\end{tabular}

III $\quad(55$

dias)

\begin{tabular}{lllllll}
1 & 428 & 107 & 400 & 167,5 & 2418604 & 6046511 \\
2 & 390 & 93,6 & 372 & 89,28 & 1981981 & 47567565 \\
\hline Média & 409 & 100,3 & 386 & 128,39 & 22,02 & 268,0703 \\
DP & 26,870057 & 9,4752308 & 19,798989 & 55,309892 & 308 & 293 \\
\hline
\end{tabular}




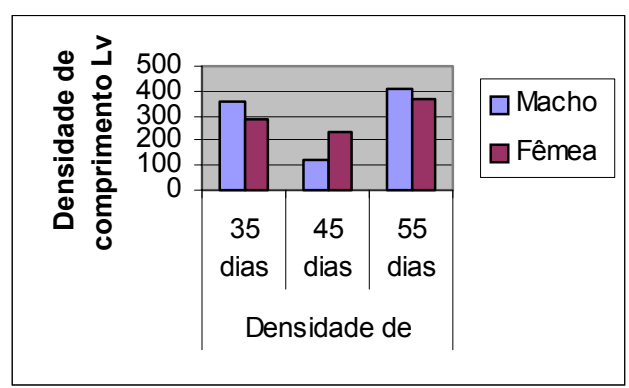

A

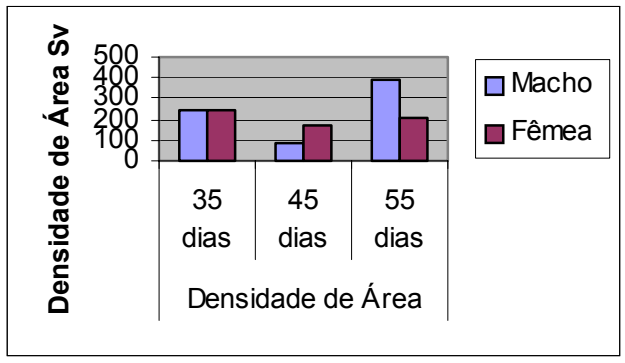

C

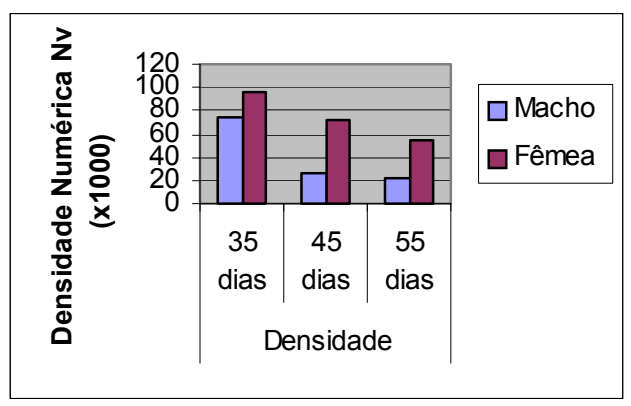

E

Figura 9 - Histograma comparando as variáveis estereológicas, densidade de comprimento do vaso (Lv), comprimento do vaso (L), densidade de superfície de área (Sv), superfície de área (S), estimação da densidade numérica vascular $\left(\mathrm{Nv}_{(\text {vasc })}\right)$; número total de vasos no órgão ( $\left.\mathrm{N}_{(\text {vasc })}\right)$ entre as faixas etárias e o sexo. A: densidade de comprimento do vaso (Lv). B: comprimento do vaso (L). C: densidade de superfície de área (Sv). D: superfície de área (S). E: estimação da densidade numérica vascular $\left(\mathrm{Nv}_{(\text {vasc })}\right)$. $\mathrm{F}$ : número total de vasos no órgão $\left(\mathrm{N}_{(\text {vasc })}\right)$. 


\section{DISCUSSÃO}

Poucos autores estudaram anteriormente a histologia e a microvascularização especificamente do timo de gatos, o que nos fez considerarmos outras espécies de animais nas análises comparativas, considerando as particularidades de cada espécie animal.

Achamos relevante enfatizar a escassez de relatos na literatura por nós compilada, que abordem aspectos da esqueletopia do órgão bem como a dos vasos sangúineos que suprem o timo do gato.

Quanto aos achados macroscópicos, estes foram semelhantes aos relatados por Daschinger (1983) que descreveu que o mesmo possui coloração rósea-pálido e aspecto visivelmente lobular. A lobação do órgão foi semelhante aos relatos de Daschinger (1983) e Silva et al. (2001) que relatam que o órgão apresenta duas porções, torácica e cervical sendo que a última apresentou-se fina e estreita.

A localização do órgão foi observada na região do mediastino cranial ao coração e ventral a traquéia, semelhantes aos relatos de Daschinger (1983).

A forma deste órgão variou individualmente entre fetos da mesma ninhada concordando com Daschinger (1983) e que o lobo direito é menor que o lobo esquerdo concordando com Hudson e Hamilton (1993).

Quanto à sintopia, nossos achados foram semelhantes aos de Daschinger (1983), onde o nervo vago localiza-se dorsalmente a porção torácica e a transição dos lobos torácicos para os lobos cervicais é demarcada por sulcos e confluindo neste sulcos foi observado a artéria e veia torácica interna.

Kato (1997) e Junqueira e Carneiro (1999) relatam que durante o desenvolvimento do timo, ramos vasculares penetram no interior do parênquima acompanhando o tecido conjuntivo, formando um espaço de tecido conjuntivo perivascular, fato este que foi observado em nosso trabalho. As arteríolas ramificam-se e aprofundam-se seguindo os septos conjuntivos, formando capilares que penetram na cortical, depois se dirigem para a medular onde desembocam em vênulas, que depois confluem para formar veias e penetram nos septos conjuntivos e saem do timo pela 
cápsula.

No tocante ao suprimento sanguíneo do timo de gatos, Daschinger (1983) descreve que este é provido pela artéria torácica interna, confirmando o que foi observado em nosso trabalho. Já Silva et al. (2001) relata que a maior contribuição vascular em timo de gatos ocorre através dos ramos fornecidos pela artéria torácica interna esquerda e do tronco braquicefálico, sendo os ramos diretos destinados ao timo provenientes das artérias torácicas internas e carótidas comuns direita e esquerda e dos troncos bicarotídeos.

Quanto à histologia do órgão concordamos com Melo e Lage (1987) e Banks (1992) os quais relatam que a cápsula e o septo do timo consistem de tecido conjuntivo frouxo e tecido adiposo.

Como os timos estudados foram isotropisados não diferenciamos as regiões corticais e medulares como citam Banks (1992) e Tizard (2000).

Os corpúsculos tímicos denominados corpúsculos de Hassals foram encontrados em todas as faixas etárias estudadas, com as células epiteliais dispostas concentricamente, como relatado por Getty (1986) e Banks (1992).

Vizi et al. (1995); Leposavić, Plećaš e Kosec (2000), Savino e Dardene (2000) e Solarović, Lalić e Leposavić (2004) descrevem a inervação dos órgãos linfóides, as interações entre os microambientes do timo e o desenvolvimento de células $T$, que é coordenado pelo sistema nervoso autônomo (SNA) e neuroendócrino, embora não tenha sido o objeto de estudo direto deste trabalho, possíveis alterações métricas do órgão, quando comparamos machos e fêmeas podem ter sofrido influência do sistema neuroendócrino.

Vizi et al. (1995), Olsen e Kovacs (1996), Kurz, et al. 1997, afirmam que mudanças no tamanho do timo na puberdade podem estar relacionados com alterações hormonais, e estes achados corroboram com a hipótese de Marchetti, Morale e Palletier (1990) onde relatam que o sistema nervoso simpático está envolvido com a resposta da célula tímica a ação hormonal por mudanças de receptores dentro da glândula tímica, confirmando nosso achados que indicam variação de tamanho das células em relação a idade e adicionando também que os hormônios esteroides sexuais influenciam na expressão de receptores nos timócitos e influenciam a diferença de 
tamanho entre machos e fêmeas fato observado neste trabalho.

O volume do timo aumenta com o desenvolvimento do animal, tendo um aumento brusco no grupo II (45 dias), acreditam que este aumento ocorre devido ao crescimento do órgão para posterior preparo para o nascimento onde se apresenta totalmente desenvolvido, já na literatura há relatos de que este desenvolvimento ocorre no período pré-natal (aproximadamente 60 dias) e no início de vida pós-natal. As variações de comprimento, espessura e largura de maneira geral apresentaram aumento conforme o desenvolvimento dos animais, estes dados também são observados no trabalho de Agreste (2005).

Para o estudo das variáveis estereológicas, necessitamos de secções isotrópicas como pré-requisitos, assim, utilizamos o método orientator modificado de acordo com Mattfeldt et al. (1990), onde o órgão aparece homogeneamente, com as mesmas características em todas as direções (MANDARIM, 1994), porém a literatura não trás a indicação de valores esteriológicos para o timo dos animais, exceção ao trabalho de Agreste (2005) que estudou o timo de cães.

Para Nyengaard, Bendtsen e Gundersen (1988) os vasos são estruturas tubulares que formam uma rede complexa e ramificada, conectados de forma única e a reconstrução física desta rede é baseada em secções seriadas. O número de capilares na rede equivalem com a conectividade, por isso usamos o princípio da conectividade ou principio de ConnEuler associado ao disector físico para a análise estereológica do timo, covalidando os achados nesta pesquisa

O método do disector físico conforme descrito por Sterio (1984); Gundersen et al. (1998a); Mayhew (1992); Coggeshall (1992); Mayhew e Gundersen (1996); Coggeshall e Lekan (1996); Gundersen et al. (1999); Pakkenberg e Gundersen (1988 e 1989) e Gagliardo (2003), foi sendo aplicado por toda a extensão do timo, para permitir que todas as regiões apresentassem as mesmas chances de serem amostradas, obedecendo a um sistema de amostragem denominado "systematic random sampling scheme".

Para a estimativa da conectividade obtivemos base dos trabalhos de Nyengaard, Bendtsen e Gundersen (1988); Nyengaard e Marcussen (1993) e Kroustrup e Gundersen (2001), assim alcançamos os valores de densidade numérica vascular 
$\left(\mathrm{Nv}_{(\mathrm{vasc})}\right)$ e número total de vasos no órgão $\left(\mathrm{N}_{(\mathrm{vasc})}\right)$, cuja comparação pode ser feita somente com o trabalho de Agreste (2005) que coletou dados estereológicos em cães.

Assim, nosso trabalho indica que a densidade numérica vascular $\left(\mathrm{Nv}_{(\mathrm{vasc})}\right)$ diminuiu gradativamente de 35 a 55 dias de gestação com diferenças de comportamento quanto ao sexo sendo maior nas fêmeas diferindo do que foi encontrado por Agreste (2005) onde os valores eram maiores nos machos e o número total de vasos no órgão $\left(\mathrm{N}_{\text {(vasc) }}\right)$ aumentaram de 35 dias para 45 dias de gestação e no final aos 55 dias diminuiu tanto nos machos como nas fêmeas, sugerindo que ocorre a diminuição pelo início da curva de involução do órgão e pelas variações de peso corpóreo, tamanho e tipo racial dos animais estudados. Neste sentido nossos achados fazem nos crer que o timo do gato sofra mais influência dos efeitos hormonais do que o timo dos cães.

A estimação da densidade do comprimento do vaso (LV) e da densidade de superfície de área (Sv) apresentam diminuição aos 45 dias de idade do feto em relação aos 55 e 35 dias de idade, sendo a densidade do comprimento do vaso maior nos machos de 35 e 55 dias, enquanto que na densidade de superfície de área os valores se apresentam com variações entre os sexos. O comprimento do vaso $(L)$ e a superfície de área (S) aumentaram gradativamente de 35 a 55 dias de idade com diferenças de comportamento quanto ao sexo, semelhantes aos achados por Agreste (2005), indicando que os sexos devam possuir uma curva de desenvolvimento diferente.

Sugere-se que as diferenças nos valores encontrados nas variações estereológicas podem estar relacionado com a variação da forma macroscópica do órgão que por sua vez pode determinar variações de dimensão deste resultando em alterações nos valores estereológicos, porquanto em muitas equações são utilizados os elementos métricos de dimensão para os cálculos da estereologia. 


\section{CONCLUSÃO}

Dos resultados obtidos podemos concluir que:

1 - O timo apresenta duas porções, torácica e cervical, onde cada uma delas apresenta um lobo direito e esquerdo em sua maioria. Possui coloração rósea-pálido, localizado em região de mediastino cranial, entre os pulmões e na base do coração a porção torácica e a porção cervical estendem-se além das costelas em sentido cranial localizada ventralmente a traquéia. A estrutura celular do timo demonstrou-se organizada com a presença de agregados concêntricos, os corpúsculos de Hassall, formados por células epiteliais mortas, sustentada por uma cápsula de tecido conjuntivo de onde parte septos que ao penetrar no órgão dividem-no em lóbulos.

2 - Ocorre variações significativas quanto à forma e as dimensões do timo entre indivíduos da mesma faixa etária.

3 - Os valores relativos ao comprimento, espessura e largura, de maneira geral, apresentaram aumento, conforme o desenvolvimento dos animais, mas com diferenças entre os sexos.

4 - As variações estereológicas referentes à densidade numérica vascular $\left(\mathrm{Nv}_{(\mathrm{vasc})}\right)$ apresentaram-se maiores nas fêmeas, ocorrendo uma diminuição gradativa com o desenvolvimento do feto, já o número total de vasos no órgão $\left(\mathrm{N}_{(\mathrm{vasc})}\right)$ apresentou valores maiores nos machos com uma dimunuição gradual. A estimação da densidade do comprimento do vaso (Lv) e da densidade de superfície de área (Sv) apresentou diminuição aos 45 dias de idade do feto em relação aos 55 e 35 dias de idade, sendo a densidade do comprimento do vaso (Lv) maior nos machos de 35 e 55 dias, enquanto que na densidade de superfície de área (Sv) os valores variaram entre os sexos. 


\section{REFERÊNCIA}

AGRESTE, F. R. Quantificação da vascularização em cães. 2005. 104 p. Tese (Mestrado em Anatomia dos Animais Domésticos) - Faculdade de Medicina Veterinária e Zootecnia, Universidade de São Paulo, são Paulo, 2005

ANDERSON, G.; MOORE, N. C.; OWEN, J. J.T.; JENKINSON, E. J. Cellular interactions in thymocyte development. Annual Review Immunology, v. 14, p. 73, 1996.

ANDERSEN, B. B.; PAKKENBERG, B. Stereological quantitation in cerebella from people with schizopherenia. Brazilian Journal Psychiatry, v. 182, p. 354-361, 2003.

APPOLINÁRIO, A. V. M. Vascularização arterial do timo de coelhos (Oryctolagus cuniculus, LINNAEUS, 1758) da raça Nova Zelândia Branco. 1998. 66p. Dissertação (Mestrado em Anatomia dos Animais Domésticos e Silvestres) - Faculdade de Medicina Veterinária e Zootecnia, Universidade de São Paulo, São Paulo, 1998.

BANKS, J. W. Sistema linfático e imunitário. In: 2. ed. São Paulo: Editora Manole, 1992. p. 370-390. .Histologia veterinária aplicada.

BAR-DAYAN, Y.; AKEK, A.; BAR-DAYAN, Y.; GOLDBERG, I.; KOPOLOVIC, J. Proliferation, apoptosis and thymic involution. Tissue\&Cell, v. 31, n. 4, p. 391-396, 1999.

BLEUL, C. C.; CORBEAUX, T.; REUTER, A.; FISCH, P.; MÖNTING, J. S. BOEHM, T. Formation of a functional thymus initiated by a postnatal epithelial progenitor cell. Nature, v. 441, n. 22, p. 992-996, 2006.

BOCKMAN, D. E. Development of the thymus. Microscopy Research and Technique, v. 38, p. 209-215, 1997.

BOEHM, T.; BLEUL, C. C. Thymus-homing precursors and the thymic microenvironment. Review: Trends in Immunology, v. 27, n. 10, p. 477-484, 2006. 
do timo em fetos de búfalo. 1997.88 p. Tese (Livre Docente) - Faculdade de Medicina Veterinária e Zootecnia, Universidade de São Paulo, São Paulo, 1997.

BOMBONATO, P. P.; SANTANA, M. I. S.; CARNEIRO E SILVA, F. O.; SEVERINO, R. S.; DRUMMOND, S. S. Irrigação do timo de fetos caprinos da raça Saanen: estudo comparativo. Brazilian Journal Veterinary Animal Science, v. 38, n. 5, 2001.

CALICH, V. L. G.; COPPIVAZ, C. A. Tecidos e órgãos linfóides. In básica. Artes médicas, 1989 p. 11-29. Imunologia

COGGESHALL, R. E. A consideration of neural counting methods. Techniques, v.15, n. 1, p. 9-13, 1992.

COGGESHALL, R. E.; LEKAN, H. A. Methods for determining numbers of cellsand synapses: a case for more uniform standards of review. The Journal of Comparative Neurology, v. 364, p 6-15, 1996.

DASCHINGER, V. E. K. Zur Topographie und Blutgefäßversorgung des Thymus der neugeborenen Hauskatze (Felis silvestris f. catus). Zeitschrift fur versuchstierkunde, v. 25 , p. $100-113,1983$.

DEHOFF, R. T.; AIGELTINGER, E. H.; CRAIG, H. R. Experimental determination of the topological properties of three-dimensional microstructures. Journal of Microscopy, $v$. 95, p. 69-91, 1972.

DRUMOND, S. S. Aspectos morfométricos e vascularização arterial do timo em suínos da raça Hampshire. 1996. 57 p. Tese (Doutorado em Anatomia dos Animais Domésticos e Silvestres) - Faculdade de Medicina Veterinária e Zootecnia, Universidade de São Paulo, São Paulo, São Paulo, 1996.

DUERSTOCK, B. S.; BAJAJ, C. L.; BORGENS, R. B. A. A comparative study of the quantitative accuracy of three-dimensional reconstructions of spinal cord from serial histological sections. Journal of Microscopy, v. 210, n. 2, p. 138-148, 2003.

GAGLIARDO, K. M. Número total de neurônios no gânglio mesentérico caudal de cães domésticos nas diferentes fases do desenvolvimento. Qual o papel da idade na população total e no tamanho dos neurônios?. 2003. 111p. Tese (Mestrado em 
Ciências)- Faculdade de Medicina Veterinária e Zootecnia, Universidade de São Paulo, São Paulo, 2003.

GEORGE, A. J. T.; RITTER, M. Thymic involution with ageing: obsolence or good housekeeping? Immunology Today, v.17, p. 267-272, 1996.

GERSHWIN, L. J.; KRAKOWKA, S.; OLSEN, R. G. The lymphoid system and cells of the lymphoid system. In: . Immunology and Immunopathology of Domestic Animals. 2. Ed. Missouri: Editora Morsby, 1995. p. 13-29.

GUETTY, R. Anatomia dos animais domésticos. 5. ed. Rio de Janeiro: Interamericana, 2000, v. 2, p. 1504-1568.

GUNDERSEN , H. J. G.; BAGGER, P.; BENDTSEN, T. F.; EVANS, S. M.; KORBO, L.; MARCUSSEN, N.; MOLLER, A.; NIELSEN, K.; NYENGAARD, J. R.; PAKKENBERG, B.; SORENSEN, F. B.; VESTERBY, A.; WEST, M. J.The new stereological tools: disector, fractionator, nuclear and point sampled intercepts and their use in pathological research and diagnosis. Acta Pathologica Microbiologica et Immunologica Scandinavica, v. 96, p. 857-881, 1998a.

GUNDERSEN , H. J. G.; BENDTSEN, T. F.; KORBO, L.; MARCUSSEN, N.; NIELSEN, K.; NYENGAARD, J. R.; PAKKENBERG, B.; SORENSEN, F. B.; VESTERBY, A.; WEST, M. J. Some new, simple and efficient stereological methods and their use in pathological research and diagnosis. Acta Pathologica Microbiologica et Immunologica Scandinavica, v. 96, p. 379-394, 1988b.

GUNDERSEN, H. J. G.; JENSEN, E. B. The eficiency of systematic sampling in stereology and its prediction. Journal of Microscopy, v. 147, p. 219-223, 1987.

HALLIWELL, R. E. W.; GORMAN, N. T. Introduction. In: immunology. Philadelphia: Editora W. B. Saunder Co, 1989. p. 1-18.

HENERY, C. C.; MAYHEW, T. M. The cerebrum and cerebellum of the fixed humans brain: efficient and unbiased estimates of volumes and cortical surfaces areas. Journal of Anatomy, v.167, p. 167-180, 1989. 
HUDSON, L. C.; HAMILTON, W. P. Atlas of feline anatomy for veterinarians, Filadélfia : W. B. Saunders Company, 1993.

HOLLÄNDER, G.; GILL, J.; ZUKLYS, S.; IWANAMI, N.; LIU, C.; TAKAHAMA, Y. Cellular and molecular events during early thymus development. Imunological Reviews, v. 209, p. 28-16, 2006.

HOWARD, C. V.; REED, M. G. Three-dimensional measurement in microscopy. In: . Unbiased stereology. Oxford: bios Scientif Publishers, 1998. p. 246.

JENSEN, E. B. V. Local stereology. New Jersey: World Scientific, 1988. 247 p.

JUNQUEIRA, L. C.; CARNEIRO, J. Sistema Imunitário e Órgãos Linfáticos. In:

Histologia Básica. Rio de Janeiro: Guanabara Koogan, 1999. p. 220-240.

KATO, S. Thymic microvascular system. Microscopy Research and Technique, v. 38, p. 287-299, 1997.

KÖNIG, H. E.; LIEBICH, H. G. Anatomia dos animais domésticos - texto e atlas, Porto Alegre: Editora Artmed, 2004. v. 2, p. 153.

KROUSTRUP, J. P.; GUNDERSEN, H. J. Estimating the number of complex particles using the ConnEuler principle. Journal of Microscopy, v.203, p. 314-320, 2001.

KURZ, B.; FEINDT, J.; GAUDECKER, V. B.; KRANZ, A.; LOPPNOW, H.; MENTLEIN, R. B- adrenoceptor-mediated effects in rat cultured thymic epithelial cells. Brazilian Journal Pharmacology, v. 120, p. 1401-1408, 1997.

LEPOSAVIĆ, G.; MIĆIĆ, M.; UGREŠIĆ, N.; BOGOJEVIĆ, M.; ISAKOVIC, K. Components of sympathetic innervation of the rat thymus during late fetal and postnatal development: histofluorescence and biochemical study. Thymus, v. 19, p. 77-87, 1992.

LEPOSAVIĆ, G.; PLEĆAS, B.; KOSEC, D. Differential effects of chronic propranolol treatment on the phenotypic profile of thymocytes from immature and adult rats.

Immunopharmacology, v. 46, p. 79-87, 2000. 
LI, -L. C.; ZHANG T.; SAIBARA, T.; NEMOTO, Y.; ONO, M.; AKISAWA, N.; IWASAKI, S.; MAEDA, T.; ONISHI, S. Thymosin a1 accelerates restoration of T cell-mediated neutralizing antibody response in immunocompromised hosts. International Immunopharmacology, v. 2, p. 39-46, 2002.

MANDARIM-DE-LACERDA, C. A. Manual de quantificação morfológica: morfologia, estereologia. 2. ed. Rio de Janeiro, 1994. 102 p.

MANDARIM-DE-LACERDA, C. A. Stereological tools in biomedical research. Anais da Academia Brasileira de Ciências, v. 75, n. 4, p 469-489, 2003.

MARCHETTI, B.; MORALE, M. C.; PALLETIER, G. Sympathetic nervous system control of the rat thymus gland maturation: autoradiographic localization of the ß2-adrenergic receptor in the thymus and presence of sexual dimorphism during ontogeny. Neurology, Endocrinology and Immunology, v. 3, p. 103-114, 1990.

MATTFELDT, T.; MALL, G.; GHAREHBAGHI, H.; MOLLER, P. Estimation of surface area and length with the orientator. Journal of Microscopy, v. 159, p. 301-317, 1990.

MAYHEW, T. M. A review of recent advances in sterology for quantifying neural structure. Journal Neurocytology, v. 21, p. 313-328, 1992.

MAYHEW, T. M; GUNDERSEN, H. J. If you assume, you can make an ass out $u$ and me: a decade of the disector for stereological counting of particles in $3 \mathrm{D}$ space. Journal of Anatomy, v. 188, n. 1, p. 1-15, 1996.

MAYHEW, T. M.; MWAMENGELE, G. L. M.; DANTZER, V. Comparative morphometry of the mammalian brain: estimates of cerebral volumes and cortical surface areas obtained from macroscopic slices. Journal of Anatomy, v. 172, p. 191-200, 1990.

MAYHEW, T. M.; OLSEN, D. R. Magnetic resonance imaging (MRI) and model-free estimates of brain volume determined using the cavalieri principle. Journal of Anatomy, v. 178, p. 133-144, 1991. 
MELO, A. M. A.; LAGE, M. C. D. Alguns aspectos da estrutura e funções do timo em Gallus domesticus. Repertório de Trabalhos do Laboratório Nacional de Investigação Veterinária, v. 19, p. 13-24, 1987.

NASCIMENTO, M. A. Vascularização arterial do timo em aves (Gallus gallus domesticus - Linnaeus, 1758) da linhagem Cobb. 2002. p. 91. Dissertação (mestrado) apresentada a Faculdade de Medicina Veterinária e Zootecnia, da Universidade de São Paulo, São Paulo, 2002.

NYENGAARD, J. R.; BENDTSEN, T. F.; GUNDERSEN, J. G. Stereological estimation of the number of capillaries, exemplified by renal glomeruli. Acta Pathologica Microbiologica et Immunologica Scandinavica, Suplement, 4, p. 92-99, 1988.

NYENGAARD, J. R.; MARCUSSEN, N. The number of glomerular capillares estimated by na unbiased and efficiente stereological method. Journal of Microscopy, v. 171, p. 27-37, 1993.

ODAKA, C.; MORISADA, T.; OIKE, Y.; SUDA, T. Distribution of lymphatic vessels in mouse thymus: immunofluorescence analysis. Cell Tissue Research, v. 325, p. 13-22, 2006.

OLSEN, N. J.; KOVACS, W. J. Gonadal steroids and immunity. Endocrine Reviews, v. 17, n. 4, 1996.

OLSON, I. A.; POSTE, M. E. The vascular supply of the thymus in the guinea-pig and pig. Immunology, v. 24, p. 253, 1973.

OWEN, J. J.; RITTER, M. Tissue interactions in the development of thymus lymphocytes. J. Exp. Med, v. 129, p. 431-432, 1969.

PAKKENBERG, B.; BOESEN, J.; ALBECK, M.; GJERRIS, F. Unbiased and efficient estimation of total ventricular volume of the brain obtained from CT-scans by stereology method. Neuroradiology, v. 31, p.413-417, 1989.

PAKKENBERG, B.; GUNDERSEN, H. J. Total number of neurons and glial cells in human brain nuclei estimated by disector and fractionator. Journal of microscopy, $\mathrm{v}$. 150, p. 1-20, 1988. 
RITTER, M. A.; CRISPE, I. N. Structure and development. In: The thymus. New York: Oxford University Press, 1992. p. 9 - 24.

SAVINO, W.; DARDENNE, M. Neuroendocrine control of thymus physiology. Endocrine Reviews, v. 21, n. 4, p. 412-443, 2000.

SCALA, G.; LANGELLA, M.; BUDETTA, G. Vascularization of the thymus in the duck. Bolletino della Societá Italiana di Biologia Sperimentale, v. 60, n. 4, p. 701-706, 1984.

SILVA, F. O. C.; SEVERINO, R. S.; SANTOS, A. L. Q.; DRUMMOND, A. S.; SILVA, M.; BOMBONATO, P. P.; REZENDE, R. J.; LIMA, E. M. M. Suprimento arterial do timo em gatos sem raça definida. Bioscience Journal, v. 17, n. 1, p. 61-66, 2001.

SMALLWOOD, J. E. The neck and shoulder regions. In veterinary anatomy, Filadélfia: W. B. Saunder Co, 1992, p.12-26.

A guided tour of

SOLAROVIĆ, P. B.; LALIĆ, L.; LEPOSAVIĆ, G. Age-dependent morphometrical changes in the thymus of male propranolol-treated rats. Annals of Anatomy, v. 186, p. 141-147, 2004.

STERIO, D. C. The unbiased estimation of number and sizes of arbitrary particles using disector. Journal of Microscopy, v. 134, p. 127-136, 1984.

TIZARD, I. Células e tecidos do sistema imunitário. In: Introdução à imunologia veterinária. 2. ed. São Paulo: Editora Roca, 1985. p. 52 -68.

TIZARD, I. Células e tecidos do sistema imunitário. In: Introdução à imunologia veterinária. 6. ed. São Paulo: Editora Roca, 2000. p. 76-92.

VERSARI, R. Le arterie timiche nell'uomo ed in altri mammiferi. Loro rapporti colle arterie tiroidee. Bolletino della Società Lancisiana degli Ospedali di Roma, v. 17, p. 64-82, 1897.

VIZI, E. S.; ORSÓ, E.; OSIPENKO, O. N.; HASKÓ, G.; ELENKOV, I. J. Neurochemical, 
electrophysiological evidence for a noradrenergic link between the sympathetic nervous system and thymocytes. Neuroscience, v. 68, n. 4, p. 1263-1276, 1995.

VON GAUDECKER, V. B. Functional histology of the human thymus. Anatomy and Embriology, v. 183, p. 1-15, 1991.

WEIBEL, E. R. Stereological methods. Practical methods for biological morphometry, London: Academic Press, 1979, p. 415.

WILKINSON, B.; OWEN, J. J. T.; JENKINSON, E. J. Factors regulating stem cell recruitment to the fetal thymus. The Journal of Immunology, v. 162, n. 7, p. 38733881, 1999.

WINDMILL, K. F.; LEE, V. W. K. Effects of castration on the lymphocytes of the thymus, spleen and lymph nodes. Tissue \& Cell, v. 30, n. 1, p. 104-111, 1998.

WINDMILL, K. F.; MEADE, B. J.; LEE, V. W. K. Effect of prepubertal gonadectomy and sex steroid treatment on the growth and lymphocyte populations of the rat thymus.

Reproduction Fertility Development, v. 5, p. 73-81, 1993.

WULFSOHN, D.; GUNDERSEN, H. J.; VEDEL JENSEN, E. B.; NYENGAARD, J. R. Volume estimation from projections. Journal of Microscopy, v. 215, p. 111-120, 2004. 